Article

\title{
Extra Virgin Olive Oil Extracts of Indigenous Southern Tuscany Cultivar Act as Anti-Inflammatory and Vasorelaxant Nutraceuticals
}

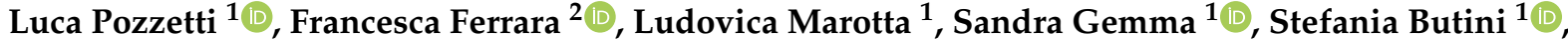 \\ Mascia Benedusi ${ }^{2}$, Fabio Fusi ${ }^{1}\left(\mathbb{D}\right.$, Amer Ahmed ${ }^{3}(\mathbb{D})$, Serena Pomponi ${ }^{4}$, Stefano Ferrari ${ }^{5}$, Matteo Perini ${ }^{6} \mathbb{D}$, \\ Anna Ramunno ${ }^{7}$, Giacomo Pepe ${ }^{7}$, Pietro Campiglia ${ }^{7}\left(\mathbb{D}\right.$, Giuseppe Valacchi ${ }^{8,9,10}\left(\mathbb{D}\right.$, Gabriele Carullo ${ }^{1, *(D)}$ \\ and Giuseppe Campiani ${ }^{1, *}$
}

Citation: Pozzetti, L.; Ferrara, F.; Marotta, L.; Gemma, S.; Butini, S.;

Benedusi, M.; Fusi, F.; Ahmed, A.; Pomponi, S.; Ferrari, S.; et al. Extra Virgin Olive Oil Extracts of Indigenous Southern Tuscany Cultivar Act as Anti-Inflammatory and Vasorelaxant Nutraceuticals. Antioxidants 2022, 11, 437. https:// doi.org/10.3390/antiox11030437

Academic Editor: Catalina Alarcòn de-la-Lastra

Received: 24 January 2022

Accepted: 17 February 2022

Published: 22 February 2022

Publisher's Note: MDPI stays neutral with regard to jurisdictional claims in published maps and institutional affiliations.

Copyright: (C) 2022 by the authors. Licensee MDPI, Basel, Switzerland. This article is an open access article distributed under the terms and conditions of the Creative Commons Attribution (CC BY) license (https:// creativecommons.org/licenses/by/ $4.0 /)$.
1 Department of Biotechnology, Chemistry and Pharmacy, DoE 2018-2022, University of Siena, 53100 Siena, Italy; luca.pozzetti@student.unisi.it (L.P.); ludovica.marotta@student.unisi.it (L.M.); gemma@unisi.it (S.G.); butini3@unisi.it (S.B.); fabio.fusi@unisi.it (F.F.)

2 Department of Neuroscience and Rehabilitation, University of Ferrara, 44121 Ferrara, Italy; frrfnc3@unife.it (F.F.); bndmsc@unife.it (M.B.)

3 Department of Life Sciences, University of Siena, 53100 Siena, Italy; aa.biotechiub@gmail.com

4 Società Agricola Olivicoltori delle Colline del Cetona Società Cooperativa, 53100 Siena, Italy; info@frantoiodelcetona.it

$5 \quad$ ISVEA s.r.l., 53036 Poggibonsi (SI), Italy; s.ferrari@isvea.it

6 Fondazione Emund Mach, 38098 San Michele all'Adige (TN), Italy; matteo.perini@fmach.it

7 Department of Pharmacy, University of Salerno, 84084 Fisciano (SA), Italy; aramunno@unisa.it (A.R.); gipepe@unisa.it (G.P.); pcampiglia@unisa.it (P.C.)

8 Department of Animal Science, Plants for Human Health Institute, NC State University, Kannapolis, NC 28081, USA; gvalacc@ncsu.edu

9 Department of Environmental Sciences and Prevention, University of Ferrara, 44121 Ferrara, Italy

10 Department of Food and Nutrition, Kyung Hee University, Seoul 02447, Korea

* Correspondence: gabriele.carullo@unisi.it (G.C.); giuseppe.campiani@unisi.it (G.C.)

\begin{abstract}
Extra virgin olive oil (EVOO) is the typical source of fats in the Mediterranean diet. While fatty acids are essential for the EVOO nutraceutical properties, multiple biological activities are also due to the presence of polyphenols. In this work, autochthonous Tuscany EVOOs were chemically characterized and selected EVOO samples were extracted to obtain hydroalcoholic phytocomplexes, which were assayed to establish their anti-inflammatory and vasorelaxant properties. The polar extracts were characterized via ${ }^{1} \mathrm{H}-\mathrm{NMR}$ and UHPLC-HRMS to investigate the chemical composition and assayed in CaCo-2 cells exposed to glucose oxidase or rat aorta rings contracted by phenylephrine. Apigenin and luteolin were found as representative flavones; other components were pinoresinol, ligstroside, and oleuropein. The extracts showed anti-inflammatory and antioxidant properties via modulation of NF- $\mathrm{kB}$ and Nrf2 pathways, respectively, and good vasorelaxant activity, both in the presence and absence of an intact endothelium. In conclusion, this study evaluated the nutraceutical properties of autochthonous Tuscany EVOO $c v$., which showed promising anti-inflammatory and vasorelaxant effects.
\end{abstract}

Keywords: olive oil; traceability quality; food origin; luteolin; oleuropein; CaCo-2 cells; Nrf2; NF-кB

\section{Introduction}

The Mediterranean diet (MD) is nowadays considered a philosophy of life, in addition to being a beneficial lifestyle [1]. This diet limits the incidence rates of cardiovascular and neurodegenerative diseases, cancer, and metabolic disorders associated with reactive oxygen species (ROS) [2]. Since MD is based on the typical autochthonous fauna and flora of the Mediterranean countries [3], the typical source of fats is represented by extra virgin olive oil (EVOO) [4]. 
Among the bioactive compounds present in EVOO, the non-saponifiable fraction is constituted by lipophilic compounds [5], such as tocopherols, carotenoids, lutein, and carotene. EVOO also contains more hydrophilic molecules, namely phenolic compounds, such as secoiridoids [6], which contribute to its bitter taste, thereby making it highly appreciated [7]. The polar composition of the EVOO may depend on the cultivar, ripening, and harvesting methods, but also on technological parameters, such as milling, malaxation, separation phases, and storage or distribution factors [8].

The consumption of 30-50 g/day of EVOO is able to prevent many pathologies [9]. EVOO has been frequently reported to have anti-inflammatory and immunomodulatory activities and to reduce the risk of coronary heart disease by modulating high-density lipoprotein (HDL) and cholesterol metabolism [10]. Seminal studies have shown improvements in renal function, lipid profile, oxidative stress [11], and inflammatory parameters in patients treated with EVOO (40 mL/day) for 9 weeks [12].

Notably, EVOO is also able to improve endothelial functions [13], and these positive effects are due, at least in part, to the presence of hydrophilic components such as biophenols, which are well-recognized for their remarkable antioxidant activity [14-16].

After ingestion, the edible phenols present in EVOO should be absorbed by enterocytes to reach the target organs and exert their biological activity. Nevertheless, when biophenols are consumed within the diet, their absorption is limited by interactions with food matrices and by the actions of digestive enzymes [17].

Interestingly, recent literature data demonstrated that a combination of phytochemicals, such as physical mixture or complex matrices, was responsible for better biological effects [18]. Specifically, EVOO hydroalcoholic extracts mediated vasorelaxation in rat mesenteric arteries by activating potassium channels through an increase in intracellular $\left[\mathrm{Ca}^{2+}\right]$ [19]. EVOO extracts decreased inflammation in dendritic cells by reducing tumor necrosis factor- $\alpha$ (TNF- $\alpha$ ) and interleukin 6 (IL-6) secretion with downregulation of intracellular nitric oxide synthase (iNOS) expression [20].

In this context, we investigated EVOO extracts from olive oils produced in an Italian area highly suited to Protected Denomination of Origin (PDO) EVOO production, collected in a consortium namely Consorzio Olivicoltori delle Colline del Cetona scarl (Siena, Tuscany, Italy), an area which spans from the plains to the hills at the slope of Cetona mountain, characterized by a mild climate that is perfect for the farming of different cultivars of olive trees, including indigenous cultivars such as Leccino and Minuta di Chiusi. The latter is a rare and ancient olive cultivar, which flourishes only in this part of South Tuscany. This cv., which is different from the more famous Minuta cultivars from Sicily and Calabria, shares with them a high resistance to low temperatures and to the olive fruit fly (Bactrocera oleae) [21].

This Minuta olive oil is very delicate and rich in subtle fruity notes with floral aromas; to the best of our knowledge, this is the first attempt at promoting the biological properties of this specific $c v$. grown in Tuscany.

We report here the chemical characterization of 18 EVOO samples in terms of acidity, peroxide values, tocopherols, biophenols, and polyphenols. Based on these results, we further selected three representative samples (O_05, O_10, and O_15) based on the rare, ancient, and indigenous cultivar Minuta di Chiusi (O_15) and the indigenous monocultivar Leccino (O_10), while O_05 derives from different cultivars (Leccino, Frantoio, Morello, Moraiolo, and Greggiolo). Liquid-liquid extraction was performed to obtain hydroalcoholic extracts (OE), which were then submitted to ${ }^{1} \mathrm{H}$ NMR and UHPLC-HRMS experiments for qualitative characterization in terms of bioactive phenols. Then, we evaluated the antioxidant and anti-inflammatory properties of EVOO polar extracts in human intestinal colorectal cells (CaCo-2 cells), where an oxidative stress stimulus was induced by the exposure to the enzyme glucose oxidase (GO). The EVOO extracts were also analyzed to assess their vasorelaxation potential in rat aorta rings. Overall, the extracts promoted a good antioxidant and anti-inflammatory response in the $\mathrm{CaCo}-2$ cell line by modulating the expression of specific inflammatory mediators such as Nrf2, IL-6, and iNOS. When tested in both endothelium-intact and -denuded rat aorta rings, OE_15 showed significant 
vasorelaxation, while in denuded aorta rings $\mathrm{OE} \_05$ and $\mathrm{OE} \_10$ proved to be worthy vasorelaxant agents. Thus, $\mathbf{O E} \_05$ and $\mathbf{O E} \_10$ showed nutraceutical potential, suggesting their beneficial effects in alleviating endothelial dysfunction. On the other hand, OE_15 could be proposed as a nutraceutical supplement to prevent hypertension.

\section{Materials and Methods}

\subsection{General Chemical Considerations}

All chemicals and solvents were purchased from Merck (Milan, Italy) as HPLC grade; the compounds used as internal or external standards were purchased from Merck (Milan, Italy) as analytical standard grade.

\subsection{EVOO Samples}

EVOO samples were collected from different farms located in a small area of the southern province of Siena, Tuscany. The olive trees from different $c v$., including Frantoio, Leccino, Minuta di Chiusi, Moraiolo, Greggiolo, and others, were grown at different altitudes, in a range between 300 and $600 \mathrm{~m}$ above sea level. The fruits were collected between 20 October 2020 and 26 November 2020 and cold-milled no more than $12 \mathrm{~h}$ after the harvest at the olive oil mill "Olivicoltori delle Colline del Cetona S.c.a.r.l.", S.S. $321 \mathrm{~km} \mathrm{11,} 53040$ Cetona, Siena, Tuscany, Italy (Figure 1). The samples were collected on the same day of the milling and stored in dark glass bottles at $4{ }^{\circ} \mathrm{C}$ for no more than 3 days before the start of the analyses.

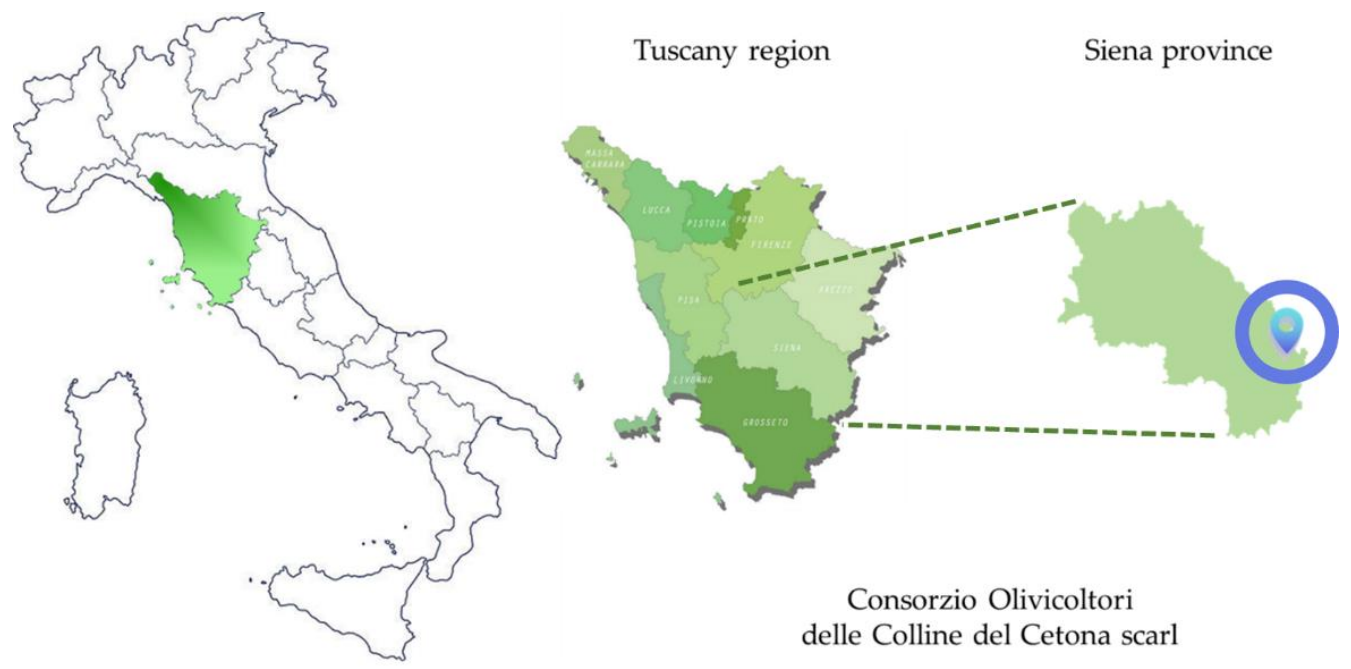

Figure 1. Geographical distribution of the samples of EVOO.

\subsection{Determination of Free Fatty Acids}

The free fatty acid content was determined following the Commission Regulation (EEC) No. 2568/91 of 11 July 1991 [22]. Briefly, an exactly weighted amount of about $10 \mathrm{~g}$ of EVOO sample was solubilized in $100 \mathrm{~mL}$ of a freshly prepared solution of ethanol and diethyl ether (1:1 ratio), neutralized with a solution of $\mathrm{KOH} 0.1 \mathrm{~N}$ in ethanol, with the addition of $0.3 \mathrm{~mL}$ of phenolphthalein solution $(10 \mathrm{~g} / \mathrm{L}$ in absolute ethanol) as an indicator. The sample solution was then titrated while stirring with the $\mathrm{KOH}$ solution until the indicator changed. The acidity value, expressed as a percentage of oleic acid by weight, was the result of an arithmetic mean between two determinations from the same sample of olive oil.

\subsection{Determination of Peroxide Value}

The determination of peroxide value was carried out following the Commission Implementing Regulation (EU) No. 1348/2013 of December 2013 [23]. Briefly, an exactly weighted amount of about $1.5 \mathrm{~g}$ of olive oil was solubilized in $10 \mathrm{~mL}$ of chloroform into a ground glass-stoppered flask; then, $15 \mathrm{~mL}$ of acetic acid was added, followed by $1 \mathrm{~mL}$ 
of freshly prepared saturated aqueous solution of KI. The stopper was quickly inserted, then the mixture was shaken for $1 \mathrm{~min}$ and left for exactly $5 \mathrm{~min}$ in the dark at $25^{\circ} \mathrm{C}$. Then, $75 \mathrm{~mL}$ of distilled water was added and the liberated iodine was titrated with a sodium thiosulphate solution $(0.01 \mathrm{M})$ using a starch solution $(10 \mathrm{~g} / \mathrm{L}$ aqueous dispersion) as an indicator. The peroxide value, expressed in milliequivalents of active oxygen per kilogram, was the result of an arithmetic mean between two determinations from the same sample of olive oil.

\subsection{Determination of Biophenols by HPLC}

The extraction and quantitative determination of the biophenolic minor polar compounds in olive oil samples was carried out according to the International Olive Council protocol with little modification [24]. Briefly, to an exactly weighted amount of about $2.0 \mathrm{~g}$ of olive oil in a screw-cap test tube, $1 \mathrm{~mL}$ of a $0.015 \mathrm{mg} / \mathrm{mL}$ solution of syringic acid in methanol/water $(80: 20 \mathrm{v} / \mathrm{v})$ (internal standard) was added. The tube was sealed and shaken for $30 \mathrm{~s}$, then $5 \mathrm{~mL}$ of a methanol/water solution $(80: 20 \mathrm{v} / \mathrm{v})$ was added and the tube was sealed again, shaken for $1 \mathrm{~min}$, sonicated in an ultrasonic extraction bath for $15 \mathrm{~min}$, and finally centrifuged at $5000 \mathrm{rpm}$ for $25 \mathrm{~min}$. An aliquot of the supernatant was filtered through a $0.45 \mu \mathrm{m}$ PVDF filter and injected (injection volume $10 \mu \mathrm{L}$ ) into a ZORBAX ${ }^{\circledR}$ RRHT Eclipse Plus C18 (Santa Clara, CA, USA), $4.6 \times 100 \mathrm{~mm}$ UHPLC column for the determination, eluted with $\mathrm{H}_{2} \mathrm{O}\left(0.2 \% \mathrm{H}_{3} \mathrm{PO}_{4} v / v\right) / \mathrm{MeOH} / \mathrm{ACN}(96: 2: 2 \rightarrow$ 50:25:25 over $40 \mathrm{~min}, 50: 25: 25 \rightarrow 40: 30: 30$ over $5 \mathrm{~min}, 40: 30: 30 \rightarrow$ 0:50:50 over $15 \mathrm{~min}$, and 0:50:50 for $10 \mathrm{~min}$ ). The biophenol content, expressed in $\mathrm{mg} / \mathrm{kg}$, was calculated by measuring the sum of the areas of the related chromatographic peaks.

\subsection{Determination of Tocopherols by HPLC}

The determination of $\alpha_{-}^{-}, \beta-, \gamma^{-}$, and $\delta$-tocopherol was accomplished by following the UNI EN 12822:2014 p.to 5.4 protocol [25]. Briefly, an exactly weighted amount of about $2.0 \mathrm{~g}$ of olive oil was solubilized in $8 \mathrm{~mL}$ of acetone and injected (injection volume $5 \mu \mathrm{L}$ ) into a ZORBAX ${ }^{\circledR}$ Eclipse XBD-C18, $4.6 \times 150 \mathrm{~mm}, 5 \mu \mathrm{m}$ analytical column, eluted with $\mathrm{MeOH}(0.1 \%$ acetic acid $v / v) /$ AcOEt (100:0 for $3.5 \mathrm{~min}, 100: 0 \rightarrow$ 10:90 over 0.7 min, 10:90 for $2 \mathrm{~min}$ ). The tocopherol content, expressed in $\mathrm{mg} / \mathrm{kg}$, was calculated by measuring the areas of the related chromatographic peaks.

\subsection{Determination of Methyl Esters of Fatty Acids by GC}

The determination of the methyl esters of fatty acids was carried out following the Commission Implementing Regulation (EU) 2015/1833 of 12 October 2015 Annex IV, with little modification [26]. Briefly, an exactly weighted amount of about $0.1 \mathrm{~g}$ of olive oil was solubilized in $2 \mathrm{~mL}$ of isooctane and then $100 \mu \mathrm{L}$ of $\mathrm{KOH}$ solution in methanol $(2 \mathrm{~N})$ was added. The mixture was shaken for $1 \mathrm{~min}$, left to stand for $2 \mathrm{~min}$, and then $2 \mathrm{~mL}$ of $\mathrm{NaCl}$ (s.s.) was added. Finally, the mixture was centrifuged at $3500 \mathrm{rpm}$ for $5 \mathrm{~min}$ and an aliquot of the supernatant was injected into an Agilent 8890 gas chromatograph (GC) system. Methyl esters of the fatty acid content, reported as the percentage area, was calculated by measuring the areas of the related chromatographic peaks.

\subsection{Determination of Total Polyphenol Content by Folin-Ciocalteu Method}

The determination of the total polyphenolic content was based on the work of Gutfinger [27] with little modification. Briefly, to a weighted amount of $1 \mathrm{~g}$ of olive oil, $1 \mathrm{~mL}$ of $\mathrm{MeOH} / \mathrm{H}_{2} \mathrm{O}(80: 20 \mathrm{v} / \mathrm{v})$ solution was added. The mixture was shaken for $3 \mathrm{~min}$ and then centrifuged at $3500 \mathrm{rpm}$ for $5 \mathrm{~min}$. Then, $0.2 \mathrm{~mL}$ of supernatant was transferred to a flask containing $7.3 \mathrm{~mL}$ of $\mathrm{H}_{2} \mathrm{O}$ and $0.5 \mathrm{~mL}$ of Folin-Ciocalteau Reagent (FCR). Next, $2 \mathrm{~mL}$ of $\mathrm{Na}_{2} \mathrm{CO}_{3}$ aqueous solution $(20 \% \mathrm{w} / \mathrm{v})$ was added and the flask was sealed, shaken, and left to stand in the dark for at least $30 \mathrm{~min}$; after this time, the sample was subjected to spectrophotometric analysis by measuring the extinction at $750 \mathrm{~nm}$ with a Cary $50 \mathrm{Scan}^{\circledR}$ UV-Vis spectrophotometer (Santa Clara, CA, USA) using caffeic acid as the standard for 
the preparation of the calibration curves. The total phenolic content, expressed as $\mathrm{mg} / \mathrm{kg}$ of caffeic acid, was calculated as the arithmetic mean of three different determinations on the same olive oil sample.

\subsection{Preparation of Polar Fraction Extracts}

An exactly weighted amount of about $50 \mathrm{~g}$ of olive oil was dissolved in $50 \mathrm{~mL}$ of $n$-hexane and extracted three times with $30 \mathrm{~mL}$ of a $\mathrm{MeOH} / \mathrm{H}_{2} \mathrm{O}$ solution $(60: 40, v / v)$. Each extract was washed once with $50 \mathrm{~mL}$ of $n$-hexane. The combined polar fractions were combined and the solvent was evaporated to dryness under vacuum at $40{ }^{\circ} \mathrm{C}$ [28].

\subsection{0. ${ }^{1} \mathrm{H}-\mathrm{NMR}$ Analysis}

NMR analysis was conducted on a Varian $300 \mathrm{MHz}$ spectrometer (Milan, Italy) by diluting $5 \mathrm{mg}$ of each sample in $600 \mu \mathrm{L}$ of DMSO- $d_{6}$. The assignment of the resonances was performed by analyzing ${ }^{1} \mathrm{H}-\mathrm{NMR}$ characteristics and by comparison with the literature [29-31].

\subsection{UHPLC-HRMS}

HPLC analyses were performed on a Shimadzu UHPLC system, consisting of an LC-40B X3 solvent delivery module, an SPD-M40 photo diode array detector, a CTO-30A column oven, and an SIL-40C X3 autosampler. The instruments were coupled online with an LCMS-IT-TOF system (Shimadzu, Kyoto, Japan) equipped with an electrospray source (ESI) operated in negative mode. LC-MS data elaboration was performed using the LCMS solution ${ }^{\circledR}$ software (Version 3.50.346, Shimadzu). For chromatographic analysis, a Luna ${ }^{\circledR}$ Omega Polar C18 $(\mathrm{L} \times$ I.D.: $100 \times 2.1 \mathrm{~mm} \times 1.6 \mu \mathrm{m}, 100 \AA$ ) was employed (Phenomenex ${ }^{\circledR}$, Bologna, Italy). The separation was carried out by employing $\mathrm{H}_{2} \mathrm{O}$ and ACN plus $0.1 \% \mathrm{CH}_{3} \mathrm{COOH}$ as the mobile phases with the following gradient: $0-20 \mathrm{~min}$, $10-90 \% \mathrm{~B} ; 20-22 \mathrm{~min}$, isocratic to $90 \% \mathrm{~B} ; 22-24 \mathrm{~min}, 90-10 \%$; and finally $4 \mathrm{~min}$ for column re-equilibration. The flow rate and column oven were set to $0.2 \mathrm{~mL} \mathrm{~min}{ }^{-1}$ and $40{ }^{\circ} \mathrm{C}$, respectively. Data acquisition was set in the range of 200-600 $\mathrm{nm}$ and chromatograms were monitored at 280 and $330 \mathrm{~nm}$. Full-scan MS data were set to $100-1500 \mathrm{~m} / \mathrm{z}$ and MS/MS experiments were conducted in the data-dependent acquisition process. Interface and curved desolvation line temperatures were set to $250{ }^{\circ} \mathrm{C}$ while nebulizing and drying gases $\left(\mathrm{N}_{2}\right)$ were fixed at 1.5 and $10 \mathrm{~L} / \mathrm{min}$, respectively. For the prediction of the molecular formula, Formula Predictor software (Shimadzu) was used with the following settings: maximum deviation from mass accuracy of $10 \mathrm{ppm}$, fragment ion information, and nitrogen rule. The identification of compounds was based on accurate MS and MS/MS spectra, the retention times of available standards, and comparisons with the literature. Moreover, the following free online databases were consulted: ChemSpider (http:/ /www.chemspider. com, accessed on 23 Januray 2022), SciFinder Scholar (https: / / scifinder.cas.org, accessed on 23 Januray 2022), and Phenol-Explorer (www.phenol-explorer.eu, accessed on 23 January 2022). For the quantitative analysis of flavones, luteolin and apigenin were selected as external standards and their amounts were expressed as milligrams per gram of extract.

\subsection{Stable Isotope Ratio Analysis}

The ${ }^{13} \mathrm{C} /{ }^{12} \mathrm{C}$ ratio in bulk Italian olive oils was measured in one run (and weighted around $0.5 \mathrm{mg}$ ) using an isotope ratio mass spectrometer (IRMS) (Isoprime Ltd., Stockport, UK) following total combustion in an elemental analyzer (VARIO CUBE, Elementar Analysensysteme $\mathrm{GmbH}$, Dresden, Germany). The ${ }^{2} \mathrm{H} /{ }^{1} \mathrm{H}$ and ${ }^{18} \mathrm{O} /{ }^{16} \mathrm{O}$ ratios were measured in one go (around $0.5 \mathrm{mg}$ ) using an IRMS (Finnigan DELTA XP, Thermo Scientific, Milan, Italy) coupled with a pyrolyzer (Finnigan TC/EA high-temperature conversion elemental analyzer, Thermo Scientific). According to the IUPAC protocol, the values were denoted in delta in relation to the international V-PDB (Vienna-Pee Dee Belemnite) for $\delta^{13} \mathrm{C}$ and V-SMOW (Vienna-Standard Mean Ocean Water) and for $\delta^{18} \mathrm{O}$ and $\delta^{2} \mathrm{H}$, according to the following general equation: 


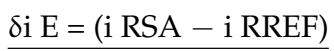

i RREF

where $\mathrm{i}$ is the mass number of the heavier isotope of element $\mathrm{E}$ (for example, ${ }^{13} \mathrm{C}$ ); RSA is the respective isotope ratio of a sample (such as for $\mathrm{C}$ : number of ${ }^{13} \mathrm{C}$ atoms/number of ${ }^{12} \mathrm{C}$ atoms or as approximation ${ }^{13} \mathrm{C} /{ }^{12} \mathrm{C}$ ); RREF is the respective isotope ratio of the internationally recognized reference material. For $\delta^{13} \mathrm{C}$, the samples were analyzed using a single working standard for normalization and calibrated against NBS-22 fuel oil (IAEA-International Atomic Energy Agency, Vienna, Austria), IAEA-CH-6 sucrose, and USGS 40 (U.S. Geological Survey, Reston, VA, USA). We did not use a calibration curve for $\delta^{13} \mathrm{C}$ as suggested by IUPAC [32] because as we used a single standard with a value similar to that of the samples. The data determined using a single anchoring point or two or three anchoring points were not significantly different [33]. The $\delta^{2} \mathrm{H}$ and $\delta^{18} \mathrm{O}$ values of defatted protein were calculated against USGS 84 (Sicilian olive oil standard $\delta^{2} \mathrm{H}=-140.4 \pm 3.1 \%$ ond $\delta^{18} \mathrm{O}=+26.38 \pm 0.5 \%$ ) and USGS 86 (tropical Vietnamese peanut oil standard, $\delta^{2} \mathrm{H}=-207.4 \pm 4.5 \%$ and $\delta^{18} \mathrm{O}=+18.76 \pm 1.03 \%$ o) through the creation of a linear equation and adoption of the "comparative equilibration procedure" [34]. One control sample was routinely included in each analytical run to check the system performance and we obtained very repeatable results over the 2 month running period. Measurement uncertainty rates, expressed as one standard deviation when measuring a sample 10 times, were $\leq 2 \%$ o for $\delta^{2} \mathrm{H}, 0.3 \%$ for $\delta^{18} \mathrm{O}$, and $0.2 \%$ or for $\delta^{13} \mathrm{C}$.

\subsection{Antioxidant-Anti-Inflammatory Activity of EVOO Extracts}

\subsubsection{Cell Culture and Treatments}

Human colorectal adenocarcinoma CaCo-2 cells were cultured in high-glucose Dulbecco's modified Eagle's medium (Corning, NY, USA) supplemented with 10\% FBS (Merck, Darmstadt, DE, Germany), $100 \mathrm{U} / \mathrm{L}$ penicillin, $100 \mu \mathrm{g} / \mathrm{mL}$ streptomycin (Gibco, ThermoFisher Scientific, Waltham, MA, USA), and 1\% of non-essential amino acids (ACL006, Microtech, Pozzuoli, NA, Italy). All cell cultures were performed at $37{ }^{\circ} \mathrm{C}$ in $5 \% \mathrm{CO}_{2}$ and 95\% air. The experiment cells were treated for $24 \mathrm{~h}$ with EVOO extracts OE_05, OE_10, and OE_15 suspended in DMSO (vehicle) at a concentration of $20 \mu \mathrm{g} / \mathrm{mL}$ and then exposed to glucose oxidase (GO) (cat 195196, MP Biomedicals ${ }^{\mathrm{TM}}$ ) at a concentration of $0.5 \mathrm{U} / \mathrm{mL}$ for $1 \mathrm{~h}$. After the different treatments and exposure, samples were collected at the indicated timepoints for subsequent immunofluorescence staining, rt-PCR (Table S1), and AmplexRed assay analysis.

\subsubsection{Cytotoxicity Study (MTT Assay)}

To evaluate the cytotoxicity of olive oil extracts and to choose the treatment dose, the cell viability test with MTT 3-(4,5-dimethylthiazol-2-yl)-2,5-diphenyltetrazolium bromide assay was performed on CaCo-2 cells and carried out as previously described [35]. Cells were grown in 96-well plates at a density of $2 \times 10^{4}$ cells/well in $200 \mu \mathrm{L}$ of media and then pre-treated for $24 \mathrm{~h}$ with different concentrations of the olive oil extracts OE_05, OE_10, and OE_15, ranging from 2 to $50 \mu \mathrm{g} / \mathrm{mL}$. After complete removal of the treatment to avoid any color interference, $50 \mu \mathrm{L}$ of serum-free media and $50 \mu \mathrm{L}$ of MTT solution $(0.5 \mathrm{mg} / \mathrm{mL})$ were added and incubated for $3 \mathrm{~h}$. The insoluble purple formazan crystals were then dissolved in $100 \mu \mathrm{L}$ of DMSO at $37 \circ \mathrm{C}$ for $15 \mathrm{~min}$. After shaking, the solution absorbance was measured using the Multiskan GO microplate spectrophotometer (Thermofisher Scientific, Milan, Italy) at $570 \mathrm{~nm}$, using $630 \mathrm{~nm}$ as a reference wavelength. The results are expressed as percentages of cell viability.

\subsubsection{AmplexRed Assay}

$\mathrm{H}_{2} \mathrm{O}_{2}$ production rate was evaluated using the Amplex Red-horseradish peroxidase (HRP) (P8375 (Merck, Darmstadt, DE, Germany) method in the media of CaCo-2 cells. As previously reported [36], cells were pre-treated for $24 \mathrm{~h}$ with olive oil extracts OE_05, 
OE_10, and OE_15 $20 \mu \mathrm{g} / \mathrm{mL}$ and then exposed for $1 \mathrm{~h}$ to $\mathrm{GO} 0.5 \mathrm{U} / \mathrm{mL}$. After GO exposure, media were replaced with fresh DMEM HG 10\% FBS and then collected directly after exposure (T0) and $30 \mathrm{~min}\left(\mathrm{~T} 30^{\prime}\right)$ and $1 \mathrm{~h}$ (T1) post-exposure. Briefly, $10 \mu \mathrm{L}$ of media for each sample was added to the reaction mixture, where in the presence of horseradish peroxidase (HRP), $\mathrm{H}_{2} \mathrm{O}_{2}$ reacted with the Amplex ${ }^{\circledR}$ Red reagent (A12222, ThermoFischer Scientific, Waltham, MA, USA), resulting in the formation of the red fluorescent resorufin product. The content of $\mathrm{H}_{2} \mathrm{O}_{2}$ was determined through a $4 \mathrm{P}$ logistic regression curve by comparing the fluorescence at $\mathrm{Ex} / \mathrm{Em} 531 / 595 \mathrm{~nm}$ with that of the $\mathrm{H}_{2} \mathrm{O}_{2}$ standard curve. Readings were performed using a Victor3 microplate reader (PerkinElmer, Inc., Waltham, MA, USA). The calibration curve was assessed using $\mathrm{H}_{2} \mathrm{O}_{2}$ solutions as the standard, and the $\mathrm{H}_{2} \mathrm{O}_{2}$ production is expressed in $\mu \mathrm{M}$.

\subsubsection{Immunofluorescence Staining}

CaCo- 2 cells were grown on coverslips at a density of $0.8 \times 10^{5}$ cells $/ \mathrm{mL}$ in 24 -well plates. After $24 \mathrm{~h}$ of pre-treatment with $20 \mu \mathrm{g} / \mathrm{mL}$ of $\mathbf{O E} \_05, \mathbf{O E} \_10$, and OE_15 olive oil extracts, cells were exposed to $1 \mathrm{~h}$ of GO $0.5 \mathrm{U} / \mathrm{mL}$ and then collected right after the end of GO exposure (T0) and $1 \mathrm{~h}$ post-exposure (T1). The immunofluorescence staining was assessed as previously described [37]. Briefly, cells were washed twice in PBS, fixed in 4\% paraformaldehyde (PFA) in PBS for $10 \mathrm{~min}$ at room temperature, and then permeabilized with $0.25 \%$ of Triton X-100 in PBS for 10 min RT. After the blocking step in 2\% BSA in PBS for $45 \mathrm{~min}$ at RT, coverslips were then incubated with primary antibody Nrf2 (Santacruz, sc$365949)$ 1:50 in 0.25\% BSA/PBS and NF-kB (8242, Cell Signaling, Danvers, MA, USA) 1:300 in $0.25 \%$ BSA $/ \mathrm{PBS}$ overnight at $4{ }^{\circ} \mathrm{C}$. The day after, samples were incubated for $1 \mathrm{~h}$ with fluorochrome-conjugated secondary antibodies (A11003 Alexa Fluor 546, A11008 Alexa Fluor 488) in PBS at BSA $0.25 \%$. Nuclei were stained with $1 \mu \mathrm{g} / \mathrm{mL}$ DAPI for $5 \mathrm{~min}$ after the removal of the secondary antibody. Coverslips were mounted onto glass slides using PermaFluor Aqueous Mounting Medium (TA-06-FM ThermoFisher Scientific, Waltham, MA, USA) and examined using the Axio Imager A2 microscope equipped with a Leica DFC350 FX camera (Carl Zeiss s.p.a, Milan, Italy) at 40× magnification. Images were quantified using ImageJ software.

\subsubsection{RNA Extraction and Quantitative Real Time PCR (qRT-PCR)}

CaCo-2 cells were seeded at a density of $4 \times 10^{5}$ cells in 6 wells plate, pre-treated for $24 \mathrm{~h}$ with the extracts $\mathrm{OE} \_05, \mathrm{OE} \_10$ and $\mathrm{OE} \_\mathbf{1 5}$, and then exposed to GO $0.5 \mathrm{U} / \mathrm{mL}$ for $1 \mathrm{~h}$. Samples were collected $6 \mathrm{~h}$ (T6) post GO treatment. Total RNA was extracted from CaCo-2 cells using the Ribospin (304-150, GeneAll) and Riboclear plus (313-150, GeneAll) kits, according to the manufacture's protocol. RNA concentration was measured using the Multiskan GO microplate spectrophotometer (Thermofisher Scientific, Milan, Italy) with MicroDROP plate (ThermoFisher Scientific, Waltham, MA, USA). cDNA was generated from $1 \mu \mathrm{g}$ of total RNA, using the IScript reverse Transcription Supermix for RT-qPCR kit (1708841, BioRad, Milan, Italy). To evaluate the mRNA levels of NQO1, GPx1, COX-2 and IL-6 genes (Table S1) quantitative real-time PCR was performed using the KAPA SYBR FAST qPCR Master Mix (2×) kit (KR0389-v10.16, KAPA BIOSYSTEMS) on a ViiA $^{\text {TM }} 7$ Real-Time PCR System (Thermofisher Scientific, Waltham, MA, USA) following the manufacturer's protocol. Gene expression was quantified by obtaining the number of cycles to reach a predetermined threshold value in the intensity of the PCR signal (CT value). Beta actin was used as reference gene, while samples were compared using the relative cycle threshold (CT). After normalization, quantitative relative gene expression was calculated by the $2^{-\Delta \Delta \mathrm{Ct}}$ method [38].

\subsection{Vasoactivity Assessments of EVOO Extracts \\ 2.14.1. Animals}

All the study procedures were in strict accordance with the European Union Guidelines for the Care and the Use of Laboratory Animals (European Union Directive 2010/63/EU) 
and approved by the Animal Care and Ethics Committee of the University of Siena and Italian Department of Health (7DF19.N.TBT). Male Wistar rats (331 $\pm 11 \mathrm{~g}$ ) were purchased from Charles River Italia (Calco, Milan, Italy) and maintained in an animal house facility at $25 \pm 1^{\circ} \mathrm{C}$ with a 12:12 $\mathrm{h}$ dark/light cycle with access to standard chow diet and water ad libitum. Animals were anaesthetized with an isoflurane (4\%) and $\mathrm{O}_{2}$ gas mixture using Fluovac (Harvard Apparatus, Holliston, MA, USA), decapitated, and exsanguinated. The thoracic aorta was immediately isolated and placed in physiological solution (namely modified Krebs-Henseleit solution (KHS)) and prepared as detailed below.

\subsubsection{Preparation of Rat Aortic Rings}

The thoracic aorta was gently cleaned of adipose and connective tissues and cut into 3-mm-wide rings. These were mounted in organ baths between two parallel L-shaped stainless steel hooks, one fixed in place and the other connected to an isometric transducer [39]. Rings were allowed to equilibrate for $60 \mathrm{~min}$ in KHS (composition in $\mathrm{mM}$ : $118 \mathrm{NaCl}, 4.75 \mathrm{KCl}, 1.19 \mathrm{KH}_{2} \mathrm{PO}_{4}, 1.19 \mathrm{MgSO}_{4}, 25 \mathrm{NaHCO}_{3}, 11.5$ glucose, $2.5 \mathrm{CaCl}_{2}$, gassed with a $95 \% \mathrm{O}_{2}-5 \% \mathrm{CO}_{2}$ gas mixture to create a $\mathrm{pH}$ of 7.4 ) under a passive tension of $1 \mathrm{~g}$. During this equilibration period, the solution was changed every $15 \mathrm{~min}$. The isometric tension was recorded using a digital PowerLab data acquisition system (PowerLab 8/30; ADInstruments). Ring viability was assessed by recording the response to $0.3 \mu \mathrm{M}$ phenylephrine (Sigma Chimica, Milan, Italy) and $60 \mathrm{mM} \mathrm{KCl}$. Where needed, the endothelium was removed by gently rubbing the lumen of the ring with forcep tips. This procedure was validated by adding $10 \mu \mathrm{M}$ acetylcholine (Sigma Chimica, Milan, Italy) at the plateau of phenylephrine-induced contraction: a relaxation greater than $70 \%$ or less than $10 \%$ denoted the presence or absence of functional endothelium, respectively [40].

\subsubsection{Effect of EVOO Extracts on Phenylephrine-Induced Contraction}

The effects of EVOO extracts, added cumulatively, were assessed on $0.3 \mu \mathrm{M}$ phenylephrineinduced contraction in either endothelium-intact or -denuded rings. Sodium nitroprusside (100 $\mu \mathrm{M}$; Riedel-De Haën AG, Seelze-Hannover, Germany) was used to prove smooth muscle functional integrity at the end of each concentration-response curve. The response to phenylephrine was taken as $100 \%$.

\subsection{Statistical Analysis}

For each of the variables tested, analysis of variance (one-way ANOVA) was used followed by Tukey's post-hoc test. Statistical significance was considered at $p<0.05$. Data are expressed as means \pm SD of duplicate determinations obtained in at least 3 independent experiments. Analyses of data, statistical analyses, and significance analyses, as measured by Student's $t$ test for unpaired samples (two tailed), were accomplished using GraphPad Prism version 5.04 (GraphPad Software Inc., San Diego, CA, USA). Data are reported as means \pm SEM; $n$ is the number of rings analyzed (indicated in parentheses), isolated from at least three animals. The pharmacological response to each EVOO extract is described in terms of the $\mathrm{IC}_{50}$.

\section{Results and Discussion}

We decided to analyze the qualitative profiles of EVOO samples in order to select the most interesting sample in terms of polyphenol content for further biological evaluation.

\subsection{Acidity and Peroxides Analysis}

Acidity and peroxide analyses were carried using standard protocols, as described in the Materials and Methods section. As reported in Table 1, all the samples showed very low acidity values, expressed as percentages of oleic acid, ranging from 0.08 to $0.15 \%$. Similarly, peroxide values, expressed as meq $\mathrm{O}_{2} / \mathrm{kg}$, appeared to be $<10$, far below the limit that the Italian legislation set as the maximum amount allowed to be labeled as EVOO (20 meq $\mathrm{O}_{2} / \mathrm{kg}$ ). Taken together, these values demonstrated the high quality of the fruits and the observation of good practices during the harvest and the milling processes. 
Table 1. Quantification of the main components in EVOO samples.

\begin{tabular}{|c|c|c|c|c|c|c|c|c|}
\hline $\begin{array}{c}\text { EVOO } \\
\text { Samples }\end{array}$ & Cultivars & $\begin{array}{c}\text { Acidity } \\
\text { (\% Oleic } \\
\text { Acid) }\end{array}$ & $\begin{array}{l}\text { Oleic Acid } \\
\text { (\%) }\end{array}$ & $\begin{array}{l}\text { Linoleic } \\
\text { Acid (\%) }\end{array}$ & $\begin{array}{c}\text { TPC } \\
(\mathrm{mg} / \mathrm{kg})\end{array}$ & $\begin{array}{l}\text { Biophenols } \\
(\mathrm{mg} / \mathrm{kg})\end{array}$ & $\begin{array}{l}\text { Tocopherols } \\
\text { (mg/kg) }\end{array}$ & $\begin{array}{c}\text { Peroxides } \\
\text { (meq } \\
\left.\mathrm{O}_{2} / \mathrm{kg}\right)\end{array}$ \\
\hline O_01 & $\begin{array}{l}\text { Leccino }(80 \%) \\
\text { Frantoio }(10 \%) \\
\text { Moraiolo }(10 \%)\end{array}$ & 0.15 & 75.48 & 6.28 & 703 & 664 & 298 & 7.70 \\
\hline O_02 & $\begin{array}{l}\text { Leccino }(10 \%) \\
\text { Frantoio }(80 \%) \\
\text { Moraiolo }(10 \%)\end{array}$ & 0.11 & 76.68 & 5.86 & 517 & 405 & 164 & 8.00 \\
\hline O_03 & $\begin{array}{c}\text { Minuta }(70 \%) \\
\text { Greggiolo }(30 \%)\end{array}$ & 0.12 & 75.72 & 6.01 & 632 & 451 & 260 & 7.20 \\
\hline O_04 & Leccino $(100 \%)$ & 0.11 & 76.92 & 5.75 & 467 & 321 & 228 & 6.80 \\
\hline O_05 & $\begin{array}{c}\text { Greggiolo }(50 \%) \\
\text { Leccino }(10 \%) \\
\text { Moraiolo }(10 \%) \\
\text { Frantoio }(10 \%) \\
\text { Morello }(20 \%)\end{array}$ & 0.11 & 77.04 & 5.95 & 406 & 314 & 221 & 6.50 \\
\hline O_06 & $\begin{array}{c}\text { Leccino }(50 \%) \\
\text { Frantoio }(50 \%)\end{array}$ & 0.14 & 77.54 & 5.63 & 474 & 293 & 228 & 8.40 \\
\hline O_07 & $\begin{array}{l}\text { Leccino }(60 \%) \\
\text { Frantoio }(30 \%) \\
\text { Moraiolo }(10 \%)\end{array}$ & 0.10 & 76.18 & 5.99 & 547 & 345 & 223 & 9.30 \\
\hline O_08 & $\begin{array}{c}\text { Leccino }(50 \%) \\
\text { Frantoio }(50 \%)\end{array}$ & 0.11 & 75.96 & 6.07 & 627 & 560 & 270 & 7.30 \\
\hline O_09 & $\begin{array}{c}\text { Frantoio }(40 \%) \\
\text { Moraiolo }(30 \%) \\
\text { Leccino }(30 \%)\end{array}$ & 0.13 & 77.34 & 5.78 & 465 & 372 & 167 & 8.50 \\
\hline O_10 & Leccino $(100 \%)$ & 0.11 & 76.45 & 5.73 & 713 & 477 & 446 & 5.30 \\
\hline O_11 & Leccino (100 \%) & 0.08 & 76.47 & 5.68 & 444 & 290 & 291 & 6.20 \\
\hline O_12 & $\begin{array}{l}\text { Leccino }(60 \%) \\
\text { Frantoio }(20 \%) \\
\text { Moraiolo }(20 \%)\end{array}$ & 0.09 & 77.20 & 5.75 & 586 & 405 & 207 & 5.70 \\
\hline O_13 & $\begin{array}{l}\text { Leccino }(80 \%) \\
\text { Frantoio }(10 \%) \\
\text { Moraiolo }(10 \%)\end{array}$ & 0.09 & 77.14 & 5.40 & 410 & 227 & 238 & 7.10 \\
\hline O_14 & $\begin{array}{c}\text { Leccino }(10 \%) \\
\text { Frantoio }(70 \%) \\
\text { Moraiolo }(20 \%)\end{array}$ & 0.09 & 75.75 & 5.98 & 602 & 434 & 254 & 6.30 \\
\hline O_15 & Minuta $(100 \%)$ & 0.13 & 75.53 & 6.34 & 681 & 553 & 239 & 4.90 \\
\hline O_16 & $\begin{array}{c}\text { Leccino }(80 \%) \\
\text { Frantoio }(10 \%) \\
\text { Moraiolo }(10 \%)\end{array}$ & 0.12 & 75.83 & 6.16 & 540 & 380 & 216 & 6.20 \\
\hline O_17 & $\begin{array}{l}\text { Leccino }(30 \%) \\
\text { Frantoio }(30 \%) \\
\text { Moraiolo }(30 \%) \\
\text { Others }(10 \%)\end{array}$ & 0.10 & 77.09 & 5.66 & 440 & 243 & 222 & 7.90 \\
\hline O_18 & $\begin{array}{c}\text { Frantoio }(80 \%) \\
\text { Leccino }(10 \%) \\
\text { Moraiolo }(10 \%)\end{array}$ & 0.10 & 76.44 & 5.98 & 529 & 385 & 261 & 7.00 \\
\hline
\end{tabular}




\subsection{Determination of Methyl Esters of Fatty Acids by GC}

This analysis was performed as described above to characterize the percentages of oleic and linoleic acids present in the EVOO samples. Table 1 lists the values of oleic acid (a monounsaturated $\omega-9$ fatty acid) and linoleic acid (a polyunsaturated $\omega-6$ fatty acid), being the most represented components of olive oil triglycerides (up to $83 \%$ of the total fatty acid content). We decided to concentrate our attention on these fatty acids, as it is now widely accepted that they can exert interesting health-promoting effects, such as anti-inflammatory, antioxidant, and cardio-protective effects $[41,42]$. These fatty acids presented similar values among all samples.

\subsection{Tocopherols}

Tocopherols represent the vitamin E content of olive oil, and they are known to play a synergistic antioxidant effect together with biophenols. Moreover, a supranutritional intake of tocopherols has been reported to be beneficial in cardiovascular diseases, cancer, inflammation, and neurodegenerative diseases [43]. For these reasons, we decided to evaluate the tocopherols content of the 18 EVOO samples by following the above-mentioned protocol. As reported in Table 1, all samples display total contents of tocopherols ranging between 164 and $298 \mathrm{mg} / \mathrm{kg}$, with the noteworthy exception of $\mathbf{O} \_\mathbf{1 0}$, which possesses a remarkable value of $446 \mathrm{mg} / \mathrm{kg}$.

\subsection{Total Phenolic Content and Biophenols}

In order to evaluate the biological properties of the EVOO extracts, we performed two different analyses to elucidate the phenolic content. In particular, we applied an HPLC protocol to quantify the content of biophenols, such as the natural and oxidized derivatives of oleuropein and ligstroside, lignans, flavonoids, and phenolic acids [24]. As reported in Table 1, biophenol contents ranged from $227 \mathrm{mg} / \mathrm{kg}$ to $664 \mathrm{mg} / \mathrm{kg}$, with good values shown by $\mathbf{O} \_01$ and $\mathbf{O} \_08$, constituted by three typical Tuscan $c v$., and by $\mathbf{O} \_15$ and $\mathbf{O} \_10$, constituted only by the rare Minuta di Chiusi and the more widespread Leccino cv., respectively. Furthermore, the total phenolic content (TPC) was measured using the Folin-Ciocalteu method, a recognized protocol for the quantitative determination of total phenolic compounds. Generally, all EVOO samples displayed good TPC values ranging from 406 to $713 \mathrm{mg} / \mathrm{kg}$, with O_01, O_03, O_08, O_10, O_14, and O_15 being the richest samples $(600$ to $700 \mathrm{mg} / \mathrm{kg}$ ). Based on their TPC and biophenols values, we selected three samples, namely $\mathbf{O} \_\mathbf{0 5}, \mathbf{O} \_\mathbf{1 0}$, and $\mathbf{O} \_\mathbf{1 5}$, to obtain their hydroalcoholic extracts, which were used to evaluate the biological properties of the phenolics present in representative EVOOs from Siena area. In particular, O_15 was selected due to its high TPC value $(682 \mathrm{mg} / \mathrm{kg})$ and because it is entirely produced from Minuta di Chiusi olives. Although $\mathbf{O} \_10$ was selected mainly for its high TPC value $(713 \mathrm{mg} / \mathrm{kg})$, it is noteworthy that it came from Leccino monocultivar, a cv. that is widespread in Italy. On the other hand, $\mathbf{O} \_05$ was chosen as a representative sample of intermediate TPC values, but also for its miscellaneous composition in terms of $c v$.

\subsection{Isotopic Ratio Mass Spectrometry}

It is widely known that EVOO, and Italian EVOO above all, is one of the main food products subjected to fraud. For this reason, we decided to submit some of the olive oil samples to the stable isotope ratio analysis, which by means of isotope ratio mass spectrometry (IRMS) can assay the content of the stable isotopes of some elements $(\mathrm{H}$, $\mathrm{C}, \mathrm{O}$ in this case) that are related to agricultural practices and pedoclimatic features of the specific geographical area where the olive trees are grown. Specifically, the isotopic ${ }^{13} \mathrm{C} /{ }^{12} \mathrm{C},{ }^{18} \mathrm{O} /{ }^{16} \mathrm{O}$, and ${ }^{2} \mathrm{H} /{ }^{1} \mathrm{H}$ ratios change according to different factors, such as latitude, altitude, climate conditions, and distance from the sea [44]. In Table 2, the above-mentioned isotopic ratios for $6 \mathrm{EVOO}$ samples are reported, with the future aim of creating a database of the stable isotopic ratios of local olive oil samples from different $c v$., which can be applied to certify the origin and quality of the products. 
Table 2. Stable isotopic ratios of six EVOO samples.

\begin{tabular}{|c|c|c|c|c|c|}
\hline $\begin{array}{c}\text { EVOO } \\
\text { Samples }\end{array}$ & Cultivars & $\begin{array}{l}\text { Altitude } \\
\text { (m asl) }\end{array}$ & $\begin{array}{l}{ }^{13} C /{ }^{12} C\left(\delta^{13} C\right) \\
\text { (\%o vs. V-PDB) }\end{array}$ & $\begin{array}{c}{ }^{18} \mathrm{O} /{ }^{16} \mathrm{O}\left(\delta^{18} \mathrm{O}\right) \\
(\% \text { vs. V-SMOW) }\end{array}$ & $\begin{array}{c}{ }^{2} \mathrm{H} /{ }^{1} \mathrm{H}\left(\delta^{2} \mathrm{H}\right) \\
\text { (\%o vs. V-SMOW) }\end{array}$ \\
\hline O_05 & $\begin{array}{c}\text { Greggiolo }(50 \%) \\
\text { Leccino }(10 \%) \\
\text { Moraiolo }(10 \%) \\
\text { Frantoio }(10 \%) \\
\text { Morello }(20 \%)\end{array}$ & 450 & $-30.2 \%$ & $23.2 \%$ & $-146 \%$ \\
\hline O_08 & $\begin{array}{c}\text { Leccino }(50 \%) \\
\text { Frantoio }(50 \%)\end{array}$ & 350 & $-30.9 \%$ & $22.8 \%$ & $-149 \%$ \\
\hline O_09 & $\begin{array}{l}\text { Frantoio }(40 \%) \\
\text { Moraiolo }(30 \%) \\
\text { Leccino }(30 \%)\end{array}$ & 300 & $-30.1 \%$ & $23.2 \%$ & $-150 \%$ \\
\hline O_10 & Leccino $(100 \%)$ & 300 & $-30.5 \%$ & $22.1 \%$ & $-148 \%$ \\
\hline O_15 & Minuta $(100 \%)$ & 330 & $-29.6 \%$ & $23.5 \%$ & $-149 \%$ \\
\hline O_16 & $\begin{array}{c}\text { Leccino }(80 \%) \\
\text { Frantoio }(10 \%) \\
\text { Moraiolo }(10 \%)\end{array}$ & 600 & $-30.5 \%$ & $23.2 \%$ & $-150 \%$ \\
\hline
\end{tabular}

\subsection{Extraction and Chemical Characterization via ${ }^{1} H$ NMR and HRMS}

As described in the material and methods section, starting from about $50 \mathrm{~g}$ of EVOO, we obtained different amounts of polar extracts. From O_05 we obtained $66 \mathrm{mg}$ of extract OE_05, from O_10 we obtained $71 \mathrm{mg}$ of extract $\mathbf{O E} \_10$, and from $\mathbf{O} \_15$ we obtained $63 \mathrm{mg}$ of extract $\mathrm{OE} \_15$. To verify the outcome of the extraction and to appreciate the chemical composition of the extracts, we performed ${ }^{1} \mathrm{H}$ NMR experiments to identify the peculiar signals given by the main different components. The results shown in Table 3 demonstrate the presence of the main distinguishable phenols, such as tyrosol, hydroxytyrosol, and $p$-coumaric acid; secoiridoids, such as oleuropein and oleochantal; and lignans, such as 1-acetoxypinoresinol, among others. In the aliphatic region of the spectra, these polar components signals are hidden underneath the fatty acids and mono- and diacylglycerols (chemical shifts of $\delta 2.80-2.50$ and $\delta 3.65-3.20 \mathrm{ppm}$ ) (Figure S1), suggesting a certain degree of co-extraction of some apolar compounds [29].

Table 3. ${ }^{1} \mathrm{H}$ NMR qualitative analysis of the major components in EVOO extracts OE_05, OE_10, and OE_15.

\begin{tabular}{|c|c|c|c|c|c|c|}
\hline \multirow{2}{*}{ Compound } & \multirow{2}{*}{ Assignment } & \multirow{2}{*}{${ }^{1} \mathrm{H}$ (ppm) } & \multirow{2}{*}{ Multiplicity } & \multicolumn{3}{|c|}{ Samples } \\
\hline & & & & OE_05 & OE_10 & OE_15 \\
\hline Oleuropein & $\mathrm{CHOH}$ & 9.49 & $\mathrm{~m}$ & + & + & + \\
\hline Oleocanthal & $\mathrm{CHO}$ & 9.23 & $\mathrm{~s}$ & + & + & + \\
\hline$p$-Coumaric acid & $\mathrm{CH}=\mathrm{CH}$ & 7.54 & $\mathrm{~d}$ & + & + & + \\
\hline Tyrosol (total) & - & $7.08-6.96$ & not assigned & + & + & + \\
\hline Hydrotyrosol & - & $6.54-6.41$ & not assigned & + & + & + \\
\hline Carotenoids (total) & $\mathrm{CH}$ & 6.68 & $\mathrm{~m}$ & + & + & + \\
\hline Luteolin & C6-H & 6.18 & $\mathrm{~m}$ & - & + & - \\
\hline Ligstroside & - & $4.20-4.00$ & not assigned & + & + & + \\
\hline Pinoresinol & $\mathrm{OCH}_{3}$ & 3.75 & $\mathrm{~s}$ & + & - & + \\
\hline 1-Acetoxypinoresinol & $\mathrm{OCH}_{3}$ & 3.76 & $\mathrm{~s}$ & - & + & + \\
\hline Campesterol & $\mathrm{CH}_{3-18}$ & 0.70 & $\mathrm{~s}$ & + & + & + \\
\hline$\beta$-Sitosterol & $\mathrm{CH}_{3-18}$ & 0.68 & $\mathrm{~s}$ & + & + & + \\
\hline
\end{tabular}

Note: (+) presence, $(-)$ absence.

The HRMS analysis showed the presence of those compounds identified by NMR experiments. Nevertheless, the UHPLC analysis (Table 4) revealed the presence of the same 
compounds in all the samples (Figures S2-S4 and Table S2). The principal compounds identified were oleacinic acid, oleocanthalic acid, various isomers of oleuropein, and ligstroside (aglycone and glycosides forms), although in particular two polyphenols, oleuropein and luteolin, were present in high amounts, which were experimentally calculated as reported in Figure 2.

Table 4. UHPLC-HRMS qualitative analysis of the major components in EVOO extracts OE_05, OE_10, and OE_15.

\begin{tabular}{|c|c|c|c|c|c|c|}
\hline Peak & $\begin{array}{l}\text { Retention } \\
\text { Time } \\
\text { (min) }\end{array}$ & $\begin{array}{c}{[\mathrm{M}-\mathrm{H}]^{-}} \\
(\mathrm{m} / \mathrm{z})\end{array}$ & MS/MS & $\begin{array}{l}\text { Error } \\
(\mathrm{ppm})\end{array}$ & $\begin{array}{l}\text { Proposed } \\
\text { Compound }\end{array}$ & $\begin{array}{l}\text { Molecular } \\
\text { Formula }\end{array}$ \\
\hline 00 & $3.07 \pm 0.01$ & 153.0556 & $\begin{array}{l}123.4023 \\
95.4011\end{array}$ & -0.65 & 3-Hydroxytyrosol & $\mathrm{C}_{8} \mathrm{H}_{10} \mathrm{O}_{3}$ \\
\hline 0 & $4.46 \pm 0.03$ & 137.0602 & 112.0045 & -4.37 & Tyrosol & $\mathrm{C}_{8} \mathrm{H}_{10} \mathrm{O}_{2}$ \\
\hline 1 & $6.47 \pm 0.03$ & 335.1093 & $\begin{array}{l}199.0564 \\
155.0665\end{array}$ & -8.95 & Oleacinic acid & $\mathrm{C}_{17} \mathrm{H}_{20} \mathrm{O}_{7}$ \\
\hline 2 & $8.77 \pm 0.02$ & 319.1168 & $\begin{array}{l}181.0452 \\
199.0551\end{array}$ & -5.95 & Oleocanthalic acid & $\mathrm{C}_{17} \mathrm{H}_{20} \mathrm{O}_{6}$ \\
\hline 3 & $9.41 \pm 0.02$ & 285.0410 & $\begin{array}{l}175.0382 \\
199.0373\end{array}$ & 2.10 & Luteolin & $\mathrm{C}_{15} \mathrm{H}_{10} \mathrm{O}_{6}$ \\
\hline 4 & $9.57 \pm 0.11$ & 357.1368 & $\begin{array}{l}136.0393 \\
342.0891\end{array}$ & 7.00 & Pinoresinol & $\mathrm{C}_{20} \mathrm{H}_{21} \mathrm{O}_{6}$ \\
\hline 5 & $10.14 \pm 0.19$ & 377.1205 & $\begin{array}{l}275.0829 \\
149.0197 \\
139.0074\end{array}$ & 0.7 & Oleuropein aglycone & $\mathrm{C}_{19} \mathrm{H}_{21} \mathrm{O}_{8}$ \\
\hline 6 & $10.32 \pm 0.04$ & 377.1205 & $\begin{array}{l}275.0831 \\
149.0199 \\
139.0076 \\
225.0481\end{array}$ & 0.9 & $\begin{array}{l}\text { Oleuropein aglycone } \\
\text { Isomer II }\end{array}$ & $\mathrm{C}_{19} \mathrm{H}_{21} \mathrm{O}_{8}$ \\
\hline 7 & $10.51 \pm 0.02$ & 269.0414 & $\begin{array}{l}150.0228 \\
117.0289\end{array}$ & 5.7 & Apigenin & $\mathrm{C}_{15} \mathrm{H}_{10} \mathrm{O}_{5}$ \\
\hline 8 & $10.67 \pm 0.16$ & 377.1205 & $\begin{array}{l}275.0829 \\
149.0197 \\
139.0074\end{array}$ & -4.4 & $\begin{array}{l}\text { Oleuropein aglycone } \\
\text { Isomer III }\end{array}$ & $\mathrm{C}_{19} \mathrm{H}_{21} \mathrm{O}_{8}$ \\
\hline 9 & $10.90 \pm 0.10$ & 377.1201 & $\begin{array}{l}\text { 275.0842; } \\
149.0174 \\
139.0010\end{array}$ & -5.4 & $\begin{array}{l}\text { Oleuropein aglycone } \\
\text { Isomer IV }\end{array}$ & $\mathrm{C}_{19} \mathrm{H}_{21} \mathrm{O}_{8}$ \\
\hline 10 & $11.42 \pm 0.19$ & 361.1250 & $\begin{array}{l}291.0780 \\
259.0926\end{array}$ & -4.1 & Ligstroside-aglycone & $\mathrm{C}_{19} \mathrm{H}_{22} \mathrm{O}_{7}$ \\
\hline 11 & $12.21 \pm 0.02$ & 361.1242 & $\begin{array}{l}291.0801 \\
259.0865\end{array}$ & -9.0 & $\begin{array}{l}\text { Ligstroside-aglycone } \\
\text { Isomer II }\end{array}$ & $\mathrm{C}_{19} \mathrm{H}_{22} \mathrm{O}_{7}$ \\
\hline 12 & $12.63 \pm 0.02$ & 361.1271 & $\begin{array}{l}291.0808 \\
259.0909\end{array}$ & -4.2 & $\begin{array}{l}\text { Ligstroside-aglycone } \\
\text { Isomer III }\end{array}$ & $\mathrm{C}_{19} \mathrm{H}_{22} \mathrm{O}_{7}$ \\
\hline
\end{tabular}

\subsection{Evaluation of Protective Effects of $\mathbf{O E \_ 0 5 , O E \_ 1 0 , ~ a n d ~} O E_{-} \mathbf{1 5}$ on CaCo-2 Cells}

\subsubsection{MTT Assay}

Upon arrival, EVOO extracts were suspended in $100 \mu \mathrm{L}$ of DMSO and stored at $4{ }^{\circ} \mathrm{C}$, avoiding direct light. The MTT assays for OE_05, OE_10, and OE_15 were performed on CaCo-2 cells to evaluate the non-toxic treatment dose. Cells were treated for $24 \mathrm{~h}$ with different concentration of EVOO extracts $(2,5,10,20$, and $50 \mu \mathrm{g} / \mathrm{mL})$ and DMSO at different doses (vehicle 1 and vehicle 2), suspended in completed DMEM high-glucose media.

As shown in Figure 3, the doses that led to a slight cell viability decrease were in the range of 30 to $50 \mu \mathrm{g} / \mathrm{mL}$ (less than $70 \%$ of cell viability), whereas the other doses did not display any significant differences in cell viability compared to control cells (ctrl). Hence, since the $20 \mu \mathrm{g} / \mathrm{mL}$ concentration was the highest dose not displaying toxicity on CaCo-2 cells, we decided to use EVOO extracts at this concentration to perform the experiment and ensure a possible protective effect. 


\begin{tabular}{c|c|c}
\hline \multirow{2}{*}{ Extract } & Luteolin & Apigenin \\
\cline { 2 - 3 } & \multicolumn{2}{|c}{$\mathbf{~ m g / g}$} \\
\hline OE_05 & $0.53 \pm 0.01$ & $0.24 \pm 0.01$ \\
\hline OE_10 & $0.42 \pm 0.01$ & $0.17 \pm 0.01$ \\
\hline OE_15 & $1.99 \pm 0.06$ & $0.82 \pm 0.03$ \\
\hline
\end{tabular}<smiles>O=c1cc(-c2ccc(O)c(O)c2)oc2cc(O)cc(O)c12</smiles>

Luteolin<smiles>O=c1cc(-c2ccc(O)cc2)oc2cc(O)cc(O)c12</smiles>

Apigenin

Figure 2. Quantification of luteolin and apigenin in EVOO extracts (OE).

a.

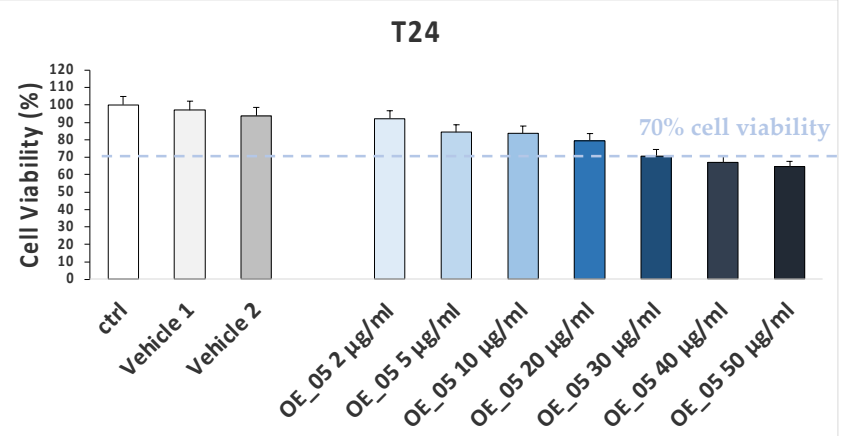

b.

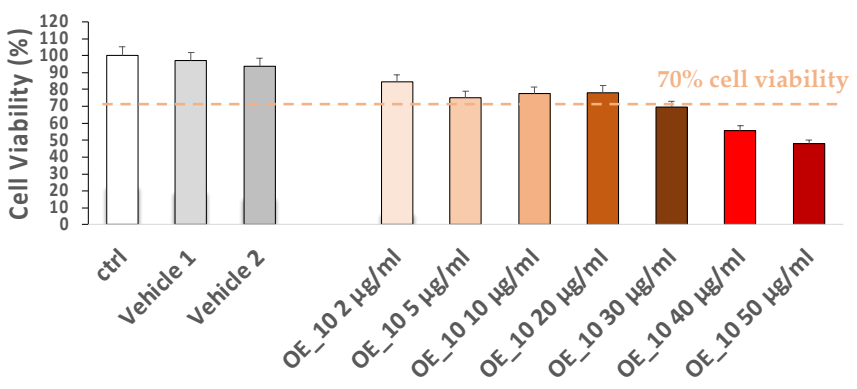

Figure 3. CaCo-2 cell viability evaluated by MTT assay after $24 \mathrm{~h}$ of pre-treatment with olive oil compound extracts OE_05 and OE_10 at different doses ranging from 2 to $50 \mu \mathrm{g} / \mathrm{mL}$. (a) Vehicle 1 represents the DMSO concentration of $\mathbf{O E} \_05$ or $\mathbf{O E} \_102 \mu \mathrm{g} / \mathrm{mL}$ solution. (b) Vehicle 2 represents DMSO concentration of OE_05 or OE_10 $50 \mu \mathrm{g} / \mathrm{mL}$ solution. Ctrl represents untreated cells. Data are given as means $\pm \mathrm{SD}$, representative of three independent experiments with at least three technical replicates each time.

\subsubsection{Antioxidant Properties of EVOO Extracts}

To evaluate the antioxidant properties of EVOO extracts, we triggered CaCo-2 cells with the oxidoreductase enzyme glucose oxidase (GO), which catalyzes the oxidation of glucose in hydrogen peroxide $\left(\mathrm{H}_{2} \mathrm{O}_{2}\right)$, a known oxidative mediator. After pre-treating CaCo-2 cells with $20 \mu \mathrm{g} / \mathrm{mL}$ OE_05, OE_10, or OE_15, we assessed an AmplexRed assay to measure the levels of $\mathrm{H}_{2} \mathrm{O}_{2}$ produced over $1 \mathrm{~h}$ of $\mathrm{GO} 0.5 \mathrm{U} / \mathrm{mL}$ treatment. As depicted in Figure 4a, GO exposure induced higher levels of $\mathrm{H}_{2} \mathrm{O}_{2}$ production at all selected timepoints. Even though OE_05 and OE_10 did not completely abrogate the $\mathrm{H}_{2} \mathrm{O}_{2}$ production compared to control cells, they could reduce the levels of $\mathrm{H}_{2} \mathrm{O}_{2}$ induced by GO. To test whether the reduction of the $\mathrm{H}_{2} \mathrm{O}_{2}$ production found in CaCo-2 cells was due to the ability of EVOO 
extracts to induce an antioxidant response responsible for counteracting the GO-induced oxidative impairment, we assessed by immunofluorescence staining the possible activation of the nuclear factor erythroid 2-related factor 2 (Nrf2). Indeed, Nrf2 activation can control the transcription of several genes involved in the cellular antioxidant response. As depicted in Figure $4 b$, the GO insult induced a slight increase in Nrf2 expression levels right after GO exposure (T0) and even more evidently after $1 \mathrm{~h}$ (T1). Interestingly, both EVOO extracts led to significant increases in Nrf2 expression levels upon GO insult, especially at T0, and these increases were still evident $1 \mathrm{~h}$ after GO exposure, even if they were lower compared to GO exposure alone. Since the activation of Nrf2 can trigger the transcription of several genes involved in the antioxidant response of the cell to restore cell homeoastasis [45], we decided to measure the transcriptional expression levels of two of the main genes under the control of Nrf2, glutathione peroxidase 1 (GPx1) and NAD(P)H dehydrogenase (quinone) 1 (NQO1). We found that GO upregulated the mRNA expression levels of both GPx1 (Figure 4c) and NQO1 (Figure 4d) $6 \mathrm{~h}$ post exposure and that the cells pre-treated with either OE_05 or OE_10 and exposed to GO displayed much higher mRNA expression levels of these two genes compared to GO-exposed cells. Since both GPx1 and NQO1 are required in the detoxification process of the cells, helping in reducing the production of radical species, their increased mRNA expression could suggest the ability of EVOO extracts to stimulate the antioxidant response of the cells and make the cells more promptly respond to the eventual oxidative insult. Indeed, although the olive oil compounds did not completely prevent the oxidative impairment induced by the GO insult as suggested by the presence of high $\mathrm{H}_{2} \mathrm{O}_{2}$ levels even after the pre-treatment, the compounds showed an ability to modulate the antioxidant response of the cells by increasing the Nrf2 expression and the transcriptional levels of Nrf2-related genes GPx1 and NQO1 upon GO insult.

\subsubsection{EVOO Extracts Showed Anti-Inflammatory Properties against Glucose} Oxidase Insult

Nowadays, oxinflammation is a well-known phenomenon characterized by the crosstalk of oxidative and inflammatory features that can influence each other to promote a more severe cellular homeostasis impairment in a variety of conditions [46-49].

To evaluate whether the altered oxidative status induced by the GO insult in CaCo-2 cells could affect and activate also an inflammatory response and whether the EVOO extracts OE_05, OE_10, and OE_15 could display anti-inflammatory properties, we measured several markers involved in the inflammatory response. Hence, immunofluorescence staining and rt-PCR analysis were carried out to investigate the expression levels of one of the most activated transcription factors, nuclear factor kappa-light-chain-enhancer of activated B cells (NF- $\kappa B$ ), as well as the mRNA expression levels of some NF- $\kappa$ B related genes such as Interleukin-6 (IL-6) and cyclooxygenase 2 (COX2), which are usually upregulated during inflammatory status. As depicted in Figure 5a, GO exposure significantly increased NF- $\kappa \mathrm{B}$ expression levels either at 0 or $1 \mathrm{~h}$ post-exposure, suggesting the activation of an inflammatory response upon the oxidative insult due to a cross-talk between oxidative and inflammatory pathways. Of note, OE_05 and OE_10 reduced the expression of NF- $\mathrm{KB}$ at both timepoints, completely restoring the NF- $\mathrm{KB}$ basal-level expression $1 \mathrm{~h}$ after the end of GO exposure, as in control cells. In addition, OE_05 and OE_10 pre-treatment completely abrogated the increased IL- 6 mRNA expression levels induced $6 \mathrm{~h}$ after GO exposure, confirming how the presence of specific substances, including flavones apigenin and luteolin, contributed to the anti-inflammatory properties [50] of the two EVOO extracts (Figure 5b). Regarding COX2, the gene did not turn out to be modulated by GO insult, as shown in Figure 5c. 
a.
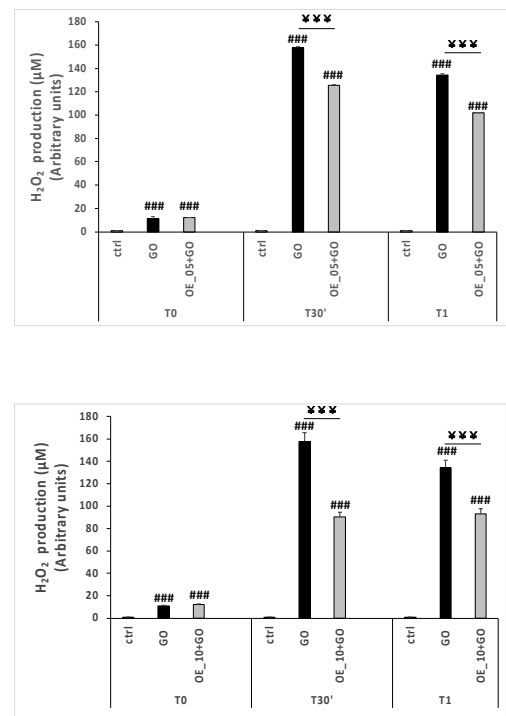

b.
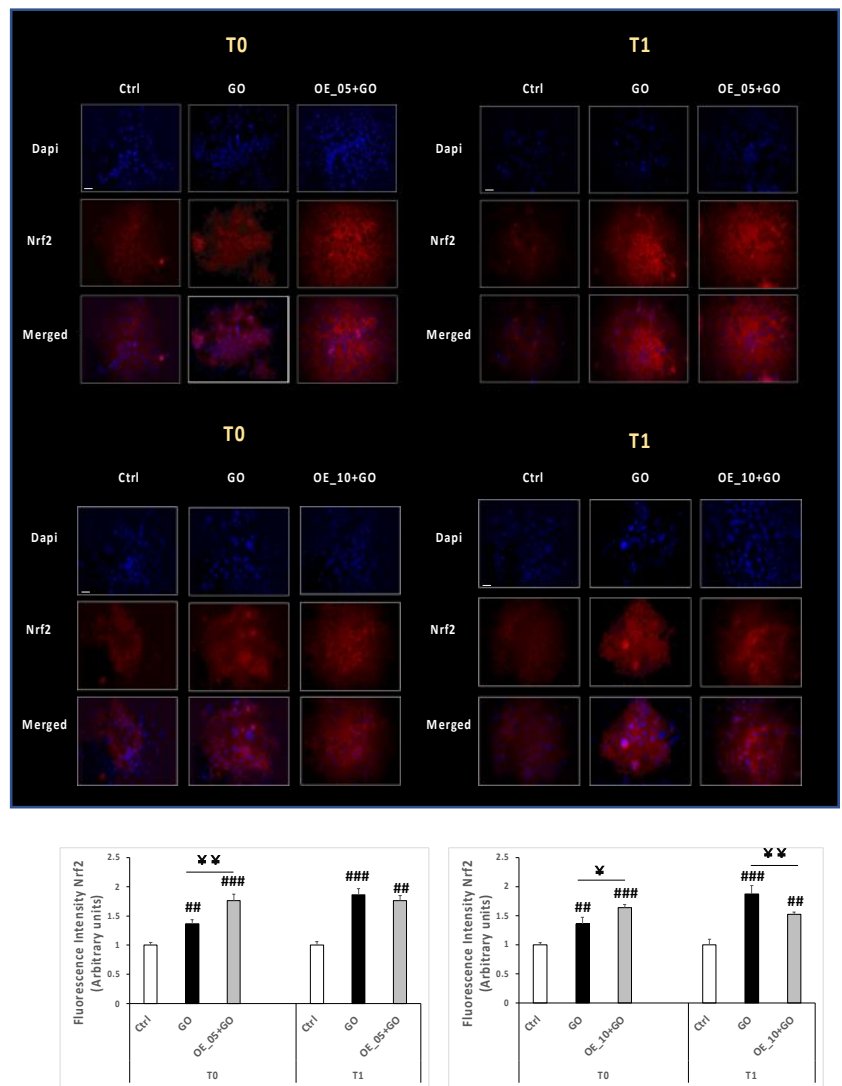

c.
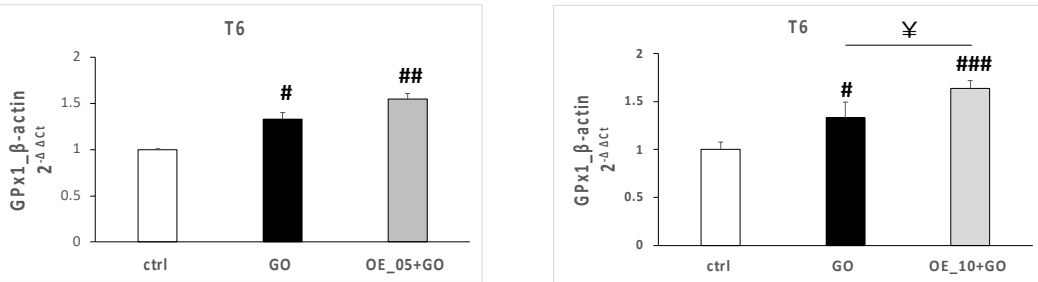

d.
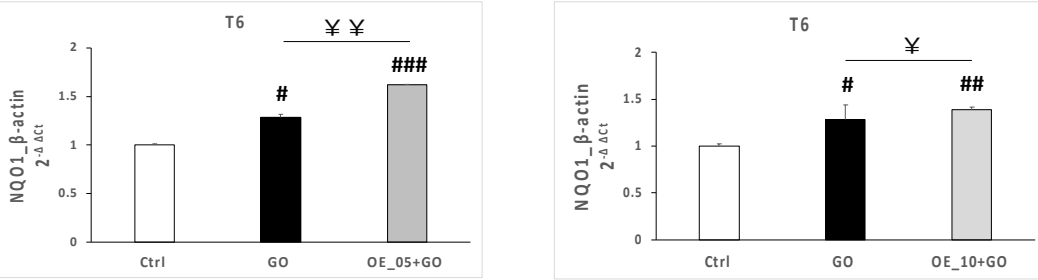

Figure 4. (a) $\mathrm{H}_{2} \mathrm{O}_{2}$ levels in media of CaCo-2 cells treated with $20 \mu \mathrm{g} / \mathrm{mL}$ OE_05 or OE_10 for $24 \mathrm{~h}$ and exposed to GO $0.5 \mathrm{U} / \mathrm{mL}$ for $1 \mathrm{~h}$ (T0, T30', T1). (b) Immunofluorescence staining of DAPI (blue) and Nrf2 (red), 0 and $1 \mathrm{~h}$ post-GO exposure in CaCo-2 cells pre-treated with $20 \mu \mathrm{g} / \mathrm{mL}$ of OE_05 or OE_10 for $24 \mathrm{~h}$. Original magnification at 40x; scale bar $=40 \mu \mathrm{m}$. The immunofluorescent signal was semiquantified by using ImageJ software (National Institutes of Health, Bethesda, MD) and the quantification graphs are displayed in the bottom panel. Transcript levels of GPx1 (c) and NQO1 (d) measured using qRT-PCR $6 \mathrm{~h}$ post-GO exposure in CaCo-2 cells pre-treated with EVOO extracts for $24 \mathrm{~h}$. Data are the results of the averages of at least three different experiments, $\# p<0.05$, $\# \# p<0.01, \# \# \#<0.001 \mathrm{GO} \pm$ OE_05 or OE_10 vs. ctrl and $¥ p<0.05, ¥ ¥ p<0.01, ¥ ¥ ¥ p<0.001 \mathrm{GO}+$ OE_05 or OE_10 vs. GO as assessed by one-way ANOVA. 
a.
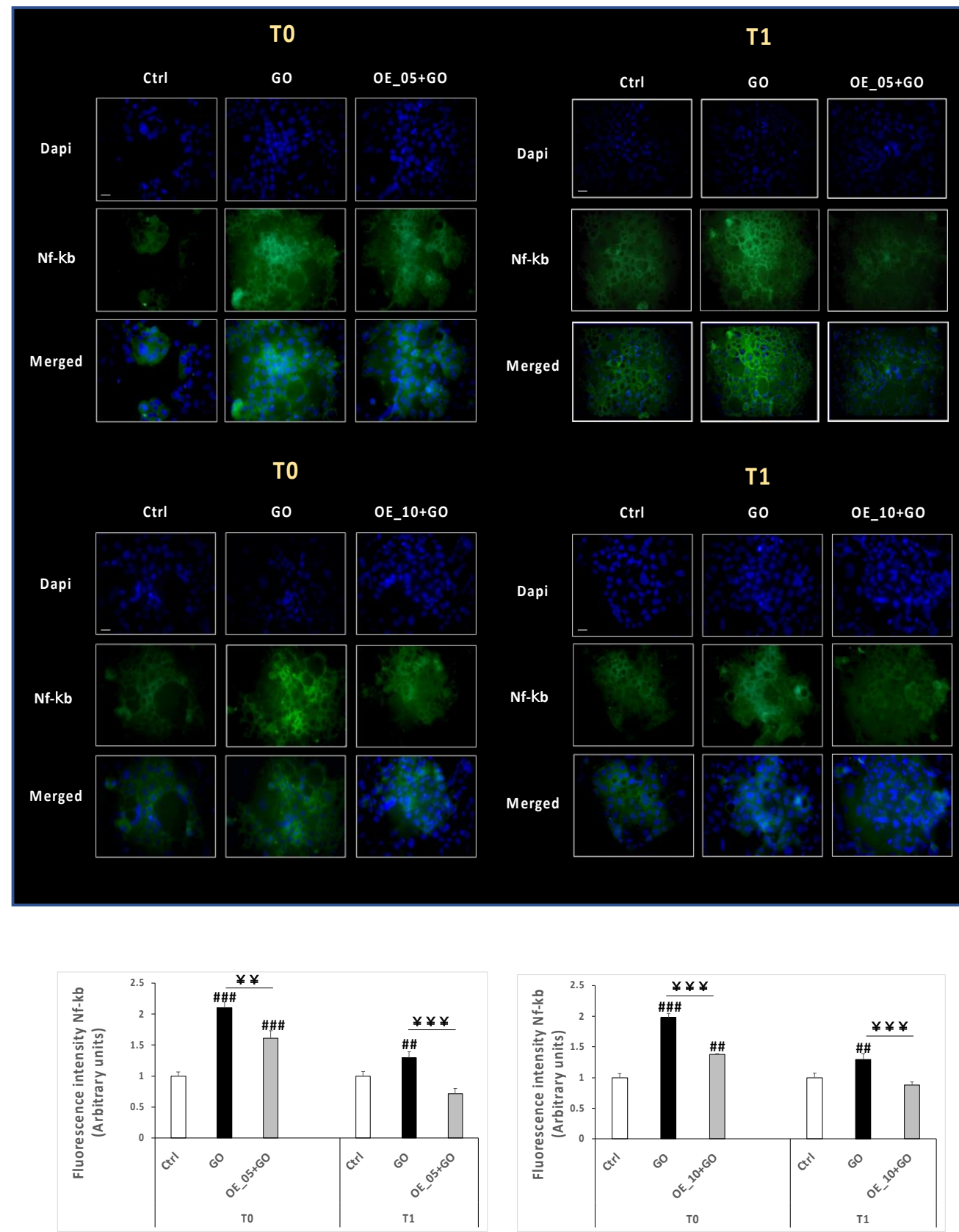

b.
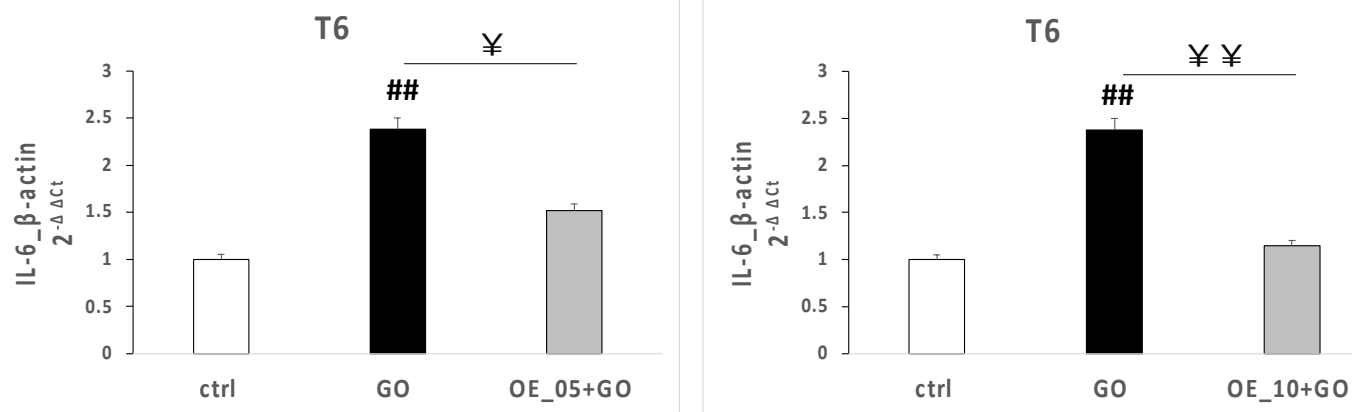

Figure 5. Cont. 
c.
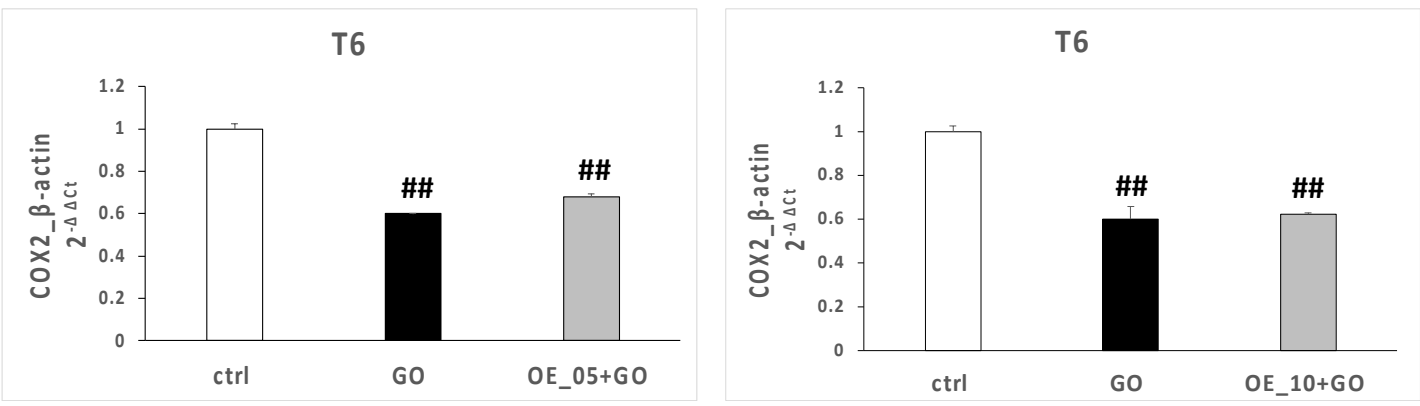

Figure 5. (a) Immunofluorescence staining of DAPI (blue) and NF- $\mathrm{kB}$ (green) in CaCo-2 cells treated with $20 \mu \mathrm{g} / \mathrm{mL}$ of $\mathbf{O E} \_\mathbf{0 5}$ or OE_10 for $24 \mathrm{~h}$ and exposed to GO $0.5 \mathrm{U} / \mathrm{mL}$ for $1 \mathrm{~h}$. Timepoints at 0 and $1 \mathrm{~h}$ post-exposure (T0, T1). Original magnification at $40 \mathrm{x}$; scale bar $=40 \mu \mathrm{m}$. The immunofluorescent signal was semiquantified using ImageJ software (National Institutes of Health, Bethesda, MD) and the quantification graphs are displayed in the bottom panel. Transcript levels of IL-6 (b) and COX2 (c) measured using qRT-PCR $6 \mathrm{~h}$ post-GO-exposure in CaCo-2 cells pre-treated with EVOO extracts for $24 \mathrm{~h}$. Data are the results of the averages of at least three different experiments, \#\# $p<0.01$, $\# \# \#<0.001 \mathrm{GO} \pm$ OE_05 or OE_10 vs. ctrl and $¥ p<0.05, ¥ ¥ p<0.01, ¥ ¥ ¥ p<0.001 \mathrm{GO}+$ OE_05 or OE_10 vs. GO as assessed by one-way ANOVA.

These data are in line with OE polyphenol content data. In fact, other studies demonstrated how EVOO phenolics were able to inhibit TLR4 (Toll-like receptor 4) activity, which in turn inhibited NF- $\mathrm{KB}$ signaling, reducing the secretion of pro-inflammatory cytokines and chemokines by PBMCs (peripheral blood mononuclear cells) such as IL-1 $\beta$ and CXCL1 (chemokine C-X-C motif Ligand 1) at the molecular level, as well as IL-6 [51].

On the other hand, EVOO extracts derived from different cultivars showed potent antiinflammatory properties thanks to a marked upregulation of the antioxidant enzymes heme oxygenase 1, NADPH quinone oxidoreductase 1, thioredoxin reductase 1, and glutathione reductase [9].

Furthermore, the phenolic compounds present in EVOO extracts showed promising anti-inflammatory properties; in particular, luteolin is able to inhibit $\mathrm{H}_{2} \mathrm{O}_{2}$-induced oxidative stress, activating the AMPK and Nrf2 pathways [52], while apigenin is able to reduce the production of inflammatory markers such as TNF- $\alpha$, TGF- $\beta$, IL-1 $\beta$, and IL-6, with significant inhibition of the active caspase-3 pathway and the pro-apoptotic Bax protein [53].

\subsection{Effects of EVOO Extracts on Phenylephrine-Induced Contraction in Rat Thoracic Aorta Rings}

The vasorelaxant activity of EVOO extracts was assessed on $\alpha_{1}$ adrenergic-receptormediated vascular smooth muscle contraction. As shown in Figure 6, OE_05, OE_10, and OE_15 caused a concentration-dependent relaxation of endothelium-denuded rings contracted by $0.3 \mu \mathrm{M}$ phenylephrine, with $\mathrm{IC}_{50}$ values of $41.8 \mu \mathrm{g} / \mathrm{mL}$ (estimated), $75.7 \mu \mathrm{g} / \mathrm{mL}$ (estimated), and $6.4 \pm 1.6 \mu \mathrm{g} / \mathrm{mL}(n=5)$. In a second series of experiments, the three extracts were assessed on rings with an intact endothelium. $\mathbf{O E} \_15$ reverted phenylephrine-induced contraction, with an $\mathrm{IC}_{50}$ value that was not significantly different from that recorded in preparations devoid of endothelium $(4.1 \pm 1.9 \mu \mathrm{g} / \mathrm{mL}, n=6 ; p=0.3866)$. However, both OE_05 and OE_10 showed markedly lower vasorelaxant activity levels, accounting for a mere $20 \%$ relaxation of the active muscle tone (Figure $6 a, b$ ). 
a
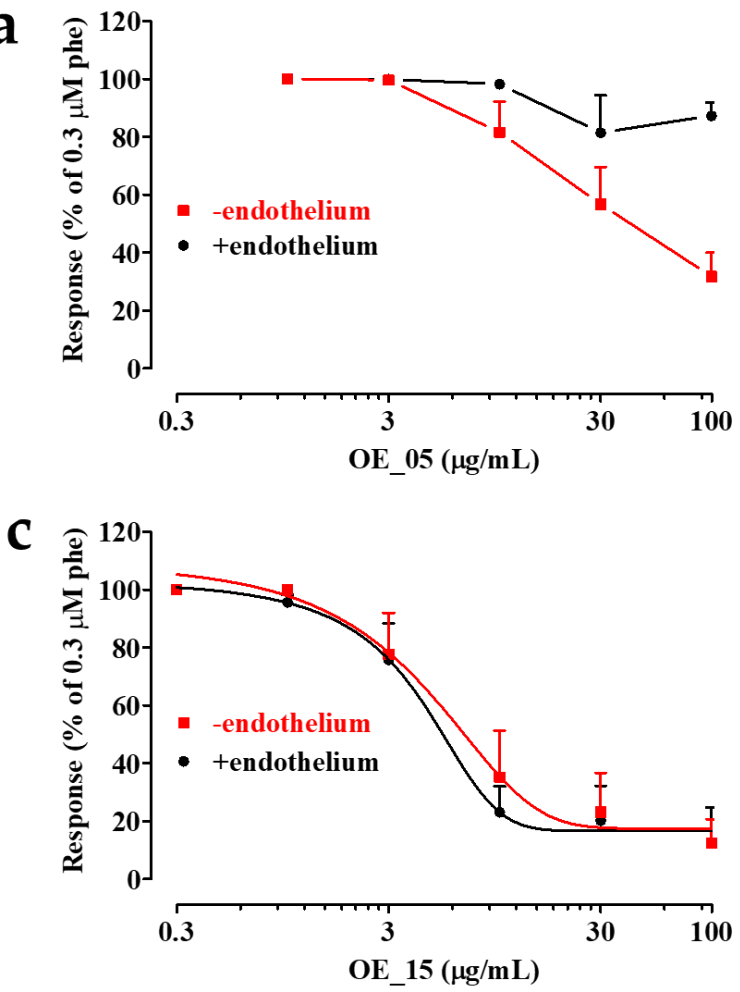

b

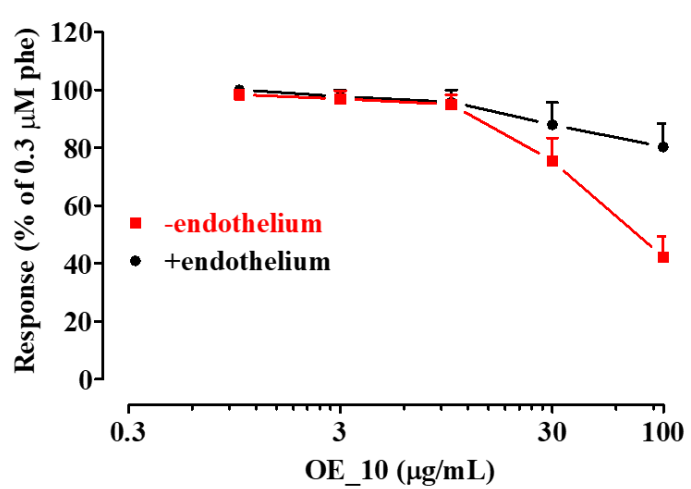

d

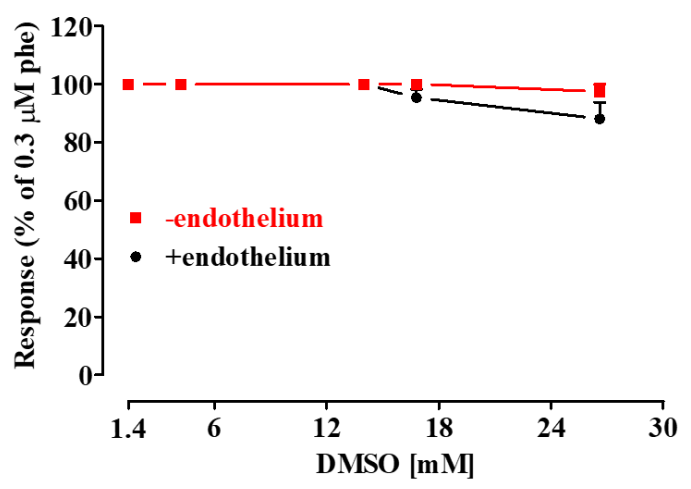

Figure 6. Effect of the EVOO extracts on phenylephrine-induced contraction of rat aorta rings. Concentration-response curves of (a) OE_05, (b) OE_10, and (c) OE_15 on endothelium-denuded (-endothelium) or endothelium-intact (+endothelium) preparations pre-contracted by $0.3 \mu \mathrm{M}$ phenylephrine (phe). (d) The effects of the vehicle DMSO are shown. In the ordinate scale, the response is reported as a percentage of the initial tension induced by phenylephrine, taken as $100 \%$. Data are means $\pm \operatorname{SEM}(n=5-9)$.

These data demonstrate that $\mathrm{OE} \_05$ and $\mathbf{O E} \_10$ stimulate the release of endotheliumderived contracting factors, which are yet to be characterized. In endothelium-denuded rings, in fact, myorelaxant activity occurred at lower concentrations as compared to endothelium-intact specimens. Contrary to $\mathrm{OE} \_05$ and $\mathrm{OE} \_10, \mathrm{OE} \_15$, besides being the most effective extract, also showed a vasorelaxant activity that was not influenced by the presence of an intact endothelium. This supports the hypothesis that the three extracts are capable of directly targeting the smooth muscle cells and activating vasorelaxant mechanisms, thereby ensuring a persistent decrease in active muscle tone, a phenomenon worthy of note. In fact, it is reasonable to think that this endothelium-independent vasorelaxant activity can counteract the reduced NO synthesis that characterizes a dysfunctional endothelium occurring in cardiovascular diseases, such as hypertension [54-56].

Taking into account the chemical composition of the extracts, their vasoactivity is likely due to the presence of apigenin and luteolin which act as potent $\mathrm{K}_{\mathrm{Ca}} 1.1$ channel stimulators [57-59], as well as oleuropein and tocopherols, although the latter are known to act mainly in an endothelium-dependent manner [60,61].

However, apigenin and luteolin are also effective $\mathrm{Ca}_{V} 1.2$ channel current stimulators [50], thereby leading to vessel contraction. Therefore, it is conceivable that the combined actions of all the components present in the extracts may be the main driver of vasorelaxation, as recently demonstrated in our laboratory [59].

Another important issue that should be taken into account is the extensive metabolism affecting polyphenol bioavailability and causing a partial loss of or even masking their bioefficacy [62,63]. These metabolites, however, can be locally converted back to the parent compound, for example through the activity of glucuronidases, thereby preserving the same activity observed in vitro [64]. 


\section{Conclusions}

In this work, we investigated autochthonous Tuscany EVOO $c v$. by evaluating their qualitative properties as source of fats. Then, selected EVOOs were subjected to extraction in order to obtain polar extracts, which were further analyzed. In particular, they were chemically characterized via ${ }^{1} \mathrm{H}-\mathrm{NMR}$ and UHPLC-HRMS analyses, showing the presence of luteolin and apigenin as representative flavones, as well as oleuropein, ligstroside, and pinoresinol, which are known to be present in EVOO polar fractions. These three extracts were then analyzed as anti-inflammatory phytocomplexes in CaCo-2 cells exposed to glucose oxidase. They reduced the inflammatory stimuli by modulating Nrf2 and NF$\mathrm{KB}$ pathways, probably due to the presence of flavone compounds. Furthermore, they promoted vasorelaxation in rat aorta rings contracted by phenylephrine. In conclusion, we showed new potential nutraceutical applications of EVOO polar extracts obtained from autochthonous Tuscany $c v$. grown in the Siena area.

Supplementary Materials: The following are available online at https:/ / www.mdpi.com/article/ 10.3390/antiox11030437/s1, Table S1. Primer Sequences. Figure S1. Representative ${ }^{1} \mathrm{H}-\mathrm{NMR}$ spectrum of OE_15. Figure S2. OE_05 $\kappa: 280 \mathrm{~nm}$. Figure S3. OE_10 $\kappa: 280 \mathrm{~nm}$. Figure S4. OE_15 $\kappa: 280 \mathrm{~nm}$. Table S2. Method validation parameters for quantitation by RP-UHPLC-PDA of flavones in olive oil extracts.

Author Contributions: Conceptualization, G.C. (Giuseppe Campiani), G.C. (Gabriele Carullo); methodology, L.P., S.F., M.P. and F.F. (Francesca Ferrara); software, S.F.; validation, G.C. (Gabriele Carullo), A.R., G.P., F.F. (Fabio Fusi) and P.C.; formal analysis, S.G. and S.B.; investigation, L.P., L.M., F.F. (Francesca Ferrara), M.B. and A.A.; data curation, S.G. and S.B.; writing-original draft preparation, L.P., G.C. (Gabriele Carullo), F.F. (Fabio Fusi), M.B., A.A. and F.F.; writing-review and editing, G.C. (Giuseppe Campiani), G.V., S.B. and S.G.; supervision, G.C. (Giuseppe Campiani) and G.V.; project administration, G.C. (Giuseppe Campiani); funding acquisition, G.C. (Giuseppe Campiani) and S.P. All authors have read and agreed to the published version of the manuscript.

Funding: PSR 2014-2020 Regione Toscana-PIF “Un Filo d'Olio DOP” n 40-misura 16.2 ECCEOLIOEcocompatibilita' e sostenibilita' ambientale del processo produttivo di Olio Extravergine di Oliva.

Institutional Review Board Statement: All the study procedures were in strict accordance with the European Union Guidelines for the Care and the Use of Laboratory Animals (European Union Directive 2010/63/EU) and approved by the Animal Care and Ethics Committee of the University of Siena and Italian Department of Health (7DF19.N.TBT).

Informed Consent Statement: Not applicable.

Data Availability Statement: The data presented in this study are available in the article and supplementary materials.

Acknowledgments: Authors thank REGIONE TOSCANA-IT, EVOO producers of the Consorzio Olivicoltori delle Colline del Cetona-IT and Gianfrancesco Baldetti-ISVEA for technical support.

Conflicts of Interest: The authors declare no conflict of interest.

\section{References}

1. Shannon, O.M.; Ashor, A.W.; Scialo, F.; Saretzki, G.; Martin-Ruiz, C.; Lara, J.; Matu, J.; Griffiths, A.; Robinson, N.; Lillà, L.; et al. Mediterranean diet and the hallmarks of ageing. Eur. J. Clin. Nutr. 2021, 75, 1176-1192. [CrossRef]

2. D'Alessandro, A.; De Pergola, G. Mediterranean Diet and Cardiovascular Disease: A Critical Evaluation of a Priori Dietary Indexes. Nutrients 2015, 7, 7863-7888. [CrossRef]

3. Davis, C.; Bryan, J.; Hodgson, J.; Murphy, K. Definition of the Mediterranean Diet; A Literature Review. Nutrients 2015, 7, 9139-9153. [CrossRef]

4. Shahbaz, M.; Sacanella, E.; Tahiri, I.; Casas, R. Chapter 17-Mediterranean diet and role of olive oil. In Olives and Olive Oil in Health and Disease Prevention, 2nd ed.; Preedy, V.R., Watson, R.R., Eds.; Academic Press: San Diego, CA, USA, 2021 ; pp. $205-214$. ISBN 978-0-12-819528-4.

5. Carullo, G.; Mazzotta, S.; Koch, A.; Hartmann, K.M.; Friedrich, O.; Gilbert, D.F.; Vega-Holm, M.; Schneider-Stock, R.; Aiello, F. New oleoyl hybrids of natural antioxidants: Synthesis and in vitro evaluation as inducers of apoptosis in colorectal cancer cells. Antioxidants 2020, 9, 1077. [CrossRef] 
6. Celano, R.; Piccinelli, A.L.; Pugliese, A.; Carabetta, S.; Di Sanzo, R.; Rastrelli, L.; Russo, M. Insights into the Analysis of Phenolic Secoiridoids in Extra Virgin Olive Oil. J. Agric. Food Chem. 2018, 66, 6053-6063. [CrossRef]

7. Lozano-Castellón, J.; López-Yerena, A.; Olmo-Cunillera, A.; Jáuregui, O.; Pérez, M.; Lamuela-Raventós, R.M.; Vallverdú-Queralt, A. Total Analysis of the Major Secoiridoids in Extra Virgin Olive Oil: Validation of an UHPLC-ESI-MS/MS Method. Antioxidants 2021, 10, 540. [CrossRef]

8. Abbattista, R.; Losito, I.; Castellaneta, A.; De Ceglie, C.; Calvano, C.D.; Cataldi, T.R.I. Insight into the Storage-Related Oxidative/Hydrolytic Degradation of Olive Oil Secoiridoids by Liquid Chromatography and High-Resolution Fourier Transform Mass Spectrometry. J. Agric. Food Chem. 2020, 68, 12310-12325. [CrossRef]

9. Barbalace, M.C.; Zallocco, L.; Beghelli, D.; Ronci, M.; Scortichini, S.; Digiacomo, M.; Macchia, M.; Mazzoni, M.R.; Fiorini, D.; Lucacchini, A.; et al. Antioxidant and Neuroprotective Activity of Extra Virgin Olive Oil Extracts Obtained from Quercetano Cultivar Trees Grown in Different Areas of the Tuscany Region (Italy). Antioxidants 2021, 10, 421. [CrossRef]

10. Otrante, A.; Trigui, A.; Walha, R.; Berrougui, H.; Fulop, T.; Khalil, A. Extra Virgin Olive Oil Prevents the Age-Related Shifts of the Distribution of HDL Subclasses and Improves Their Functionality. Nutrients 2021, 13, 2235. [CrossRef]

11. Noce, A.; Marrone, G.; Urciuoli, S.; Di Daniele, F.; Di Lauro, M.; Pietroboni Zaitseva, A.; Di Daniele, N.; Romani, A. Usefulness of Extra Virgin Olive Oil Minor Polar Compounds in the Management of Chronic Kidney Disease Patients. Nutrients 2021, 13, 581. [CrossRef]

12. Longhi, R.; Santos, A.S.e.A.d.C.; López-Yerena, A.; Rodrigues, A.P.S.; de Oliveira, C.; Silveira, E.A. The Effectiveness of Extra Virgin Olive Oil and the Traditional Brazilian Diet in Reducing the Inflammatory Profile of Individuals with Severe Obesity: A Randomized Clinical Trial. Nutrients 2021, 13, 4139. [CrossRef]

13. Njike, V.Y.; Ayettey, R.; Treu, J.A.; Doughty, K.N.; Katz, D.L. Post-prandial effects of high-polyphenolic extra virgin olive oil on endothelial function in adults at risk for type 2 diabetes: A randomized controlled crossover trial. Int. J. Cardiol. 2021, 330, 171-176. [CrossRef]

14. Carullo, G.; Governa, P.; Spizzirri, U.G.; Biagi, M.; Sciubba, F.; Giorgi, G.; Loizzo, M.R.; Di Cocco, M.E.; Aiello, F.; Restuccia, D. Sangiovese cv pomace seeds extract-fortified kefir exerts anti-inflammatory activity in an in vitro model of intestinal epithelium using caco-2 cells. Antioxidants 2020, 9, 54. [CrossRef]

15. Dini, I.; Graziani, G.; Gaspari, A.; Fedele, F.L.; Sicari, A.; Vinale, F.; Cavallo, P.; Lorito, M.; Ritieni, A. New strategies in the cultivation of olive trees and repercussions on the nutritional value of the extra virgin olive oil. Molecules 2020, 25, 2345. [CrossRef]

16. Carullo, G.; Sciubba, F.; Governa, P.; Mazzotta, S.; Frattaruolo, L.; Grillo, G.; Cappello, A.R.; Cravotto, G.; Di Cocco, M.E.; Aiello, F. Mantonico and pecorello grape seed extracts: Chemical characterization and evaluation of in vitro wound-healing and anti-inflammatory activities. Pharmaceuticals 2020, 13, 97. [CrossRef]

17. Lammi, C.; Bellumori, M.; Cecchi, L.; Bartolomei, M.; Bollati, C.; Clodoveo, M.L.; Corbo, F.; Arnoldi, A.; Mulinacci, N. Extra virgin olive oil phenol extracts exert hypocholesterolemic effects through the modulation of the LDLR pathway: In vitro and cellular mechanism of action elucidation. Nutrients 2020, 12, 1723. [CrossRef]

18. Lammi, C.; Mulinacci, N.; Cecchi, L.; Bellumori, M.; Bollati, C.; Bartolomei, M.; Franchini, C.; Clodoveo, M.L.; Corbo, F.; Arnoldi, A. Virgin Olive Oil Extracts Reduce Oxidative Stress and Modulate Cholesterol Metabolism: Comparison between Oils Obtained with Traditional and Innovative Processes. Antioxidants 2020, 9, 798. [CrossRef]

19. D’agostino, R.; Barberio, L.; Gatto, M.; Tropea, T.; De Luca, M.; Mandalà, M. Extra virgin olive oil phenols vasodilate rat mesenteric resistance artery via phospholipase c (Plc)-calcium microdomains-potassium channels (bkca) signals. Biomolecules 2021, 11, 137. [CrossRef]

20. De Santis, S.; Liso, M.; Verna, G.; Curci, F.; Milani, G.; Faienza, M.F.; Franchini, C.; Moschetta, A.; Chieppa, M.; Clodoveo, M.L.; et al. Extra virgin olive oil extracts modulate the inflammatory ability of murine dendritic cells based on their polyphenols pattern: Correlation between chemical composition and biological function. Antioxidants 2021, 10, 1016. [CrossRef]

21. Rizzo, R.; Caleca, V. Resistance to the attack of Bactrocera oleae (Gmelin) of some Sicilian olive cultivars. In Proceedings of the Olivebioteq 2006, Second International Seminar "Biotechnology and quality of olive tree products around the Mediterranean Basin”, Mazara del Vallo, Marsala, Italy, 5-10 November 2006; Volume II, pp. 35-42.

22. EU Commission. Commission Regulation (EEC) No 2568/91 of 11 July 1991 on the characteristics of olive oil and olive-residue oil and on the relevant methods of analysis. Off. J. L 1991, 248, 1.

23. EU Commission. Commission Implementing Regulation (EU) No 1348/2013 of 16 December 2013 amending Regulation (EEC) No 2568/91 on the characteristics of olive oil and olive-residue oil and on the relevant methods of analysis. OJ L 338, 17.12.2013, p. 31-67. Off. J. Eur. Union 2014, 57, 1-28.

24. International Olive Council Method of Analysis Determination of Biophenols in Olive Oils by Hplc. 2017, pp. 1-8. Available online: https: / / www.oelea.de/downloads/COI-T20-DOC-29-2009-DETERMINATION-OF-BIOPHENOLS-IN-OLIVE-OILSBY-HPLC.pdf (accessed on 24 January 2022).

25. UNI EN 12822:2014. Foodstuffs—Determination of Vitamin E by High Performance Liquid Chromatography—Measurement of $\alpha-, \beta-, \gamma-$ and $\delta$-Tocopherols. Available online: https://infostore.saiglobal.com/preview /98701590166.pdf?sku=858459_SAIG_ NSAI_NSAI_2042196 (accessed on 24 January 2022).

26. EU Commission. Commission Implementing Regulation (EU) 2015/1833 of 12 October 2015 amending Regulation (EEC) No $2568 / 91$ on the characteristics of olive oil and olive-residue oil and on the relevant methods of analysis. OJ L 266, 13.10.2015, p. 29-52. Off. J. Eur. Union 2015, 2015, 29-52. 
27. Gutfinger, T. Polyphenols in olive oils. J. Am. Oil Chem. Soc. 1981, 58, 966-968. [CrossRef]

28. Tsimidou, M.; Papadopoulos, G.; Boskou, D. Determination of phenolic compounds in virgin olive oil by reversed-phase HPLC with emphasis on UV detection. Food Chem. 1992, 44, 53-60. [CrossRef]

29. Christophoridou, S.; Dais, P. Detection and quantification of phenolic compounds in olive oil by high resolution $1 \mathrm{H}$ nuclear magnetic resonance spectroscopy. Anal. Chim. Acta 2009, 633, 283-292. [CrossRef]

30. Spizzirri, U.G.; Carullo, G.; Aiello, F.; Paolino, D.; Restuccia, D. Valorisation of olive oil pomace extracts for a functional pear beverage formulation. Int. J. Food Sci. Technol. 2021, 56, 5497-5505. [CrossRef]

31. Castejón, D.; Fricke, P.; Cambero, M.I.; Herrera, A. Automatic 1H-NMR Screening of Fatty Acid Composition in Edible Oils. Nutrients 2016, 8, 93. [CrossRef]

32. Brand, W.A.; Coplen, T.B.; Vogl, J.; Rosner, M.; Prohaska, T. Assessment of international reference materials for isotope-ratio analysis (IUPAC Technical Report). Pure Appl. Chem. 2014, 86, 425-467. [CrossRef]

33. Camin, F.; Bertoldi, D.; Santato, A.; Bontempo, L.; Perini, M.; Ziller, L.; Stroppa, A.; Larcher, R. Validation of methods for H, C, $\mathrm{N}$ and $\mathrm{S}$ stable isotopes and elemental analysis of cheese: Results of an international collaborative study. Rapid Commun. Mass Spectrom. 2015, 29, 415-423. [CrossRef]

34. Wassenaar, L.I.; Hobson, K.A. Comparative equilibration and online technique for determination of non-exchangeable hydrogen of keratins for use in animal migration studies. Isotopes Environ. Health Stud. 2003, 39, 211-217. [CrossRef]

35. Sguizzato, M.; Ferrara, F.; Hallan, S.S.; Baldisserotto, A.; Drechsler, M.; Malatesta, M.; Costanzo, M.; Cortesi, R.; Puglia, C.; Valacchi, G.; et al. Ethosomes and transethosomes for mangiferin transdermal delivery. Antioxidants 2021, 10, 768. [CrossRef] [PubMed]

36. Ferrara, F.; Pambianchi, E.; Pecorelli, A.; Woodby, B.; Messano, N.; Therrien, J.P.; Lila, M.A.; Valacchi, G. Redox regulation of cutaneous inflammasome by ozone exposure. Free Radic. Biol. Med. 2019, 152, 561-570. [CrossRef]

37. Romani, A.; Cervellati, C.; Muresan, X.M.; Belmonte, G.; Pecorelli, A.; Cervellati, F.; Benedusi, M.; Evelson, P. Keratinocytes oxidative damage mechanisms related to airbone particle matter exposure. Mech. Ageing Dev. 2018, 172, 86-95. [CrossRef] [PubMed]

38. Cervellati, F.; Woodby, B.; Benedusi, M.; Ferrara, F.; Guiotto, A.; Valacchi, G. Evaluation of oxidative damage and Nrf2 activation by combined pollution exposure in lung epithelial cells. Environ. Sci. Pollut. Res. 2020, 27, 31841-31853. [CrossRef]

39. Saponara, S.; Durante, M.; Spiga, O.; Mugnai, P.; Sgaragli, G.; Huong, T.; Khanh, P.; Son, N.; Cuong, N.; Fusi, F. Functional, electrophysiological and molecular docking analysis of the modulation of Cav1.2 channels in rat vascular myocytes by murrayafoline A. Br. J. Pharmacol. 2016, 173, 292-304. [CrossRef] [PubMed]

40. Carullo, G.; Ahmed, A.; Trezza, A.; Spiga, O.; Brizzi, A.; Saponara, S.; Fusi, F.; Aiello, F. A multitarget semi-synthetic derivative of the flavonoid morin with improved in vitro vasorelaxant activity: Role of CaV1.2 and KCa1.1 channels. Biochem. Pharmacol. 2021, 185, 114429. [CrossRef]

41. Mazzotta, S.; Governa, P.; Borgonetti, V.; Marcolongo, P.; Nanni, C.; Gamberucci, A.; Manetti, F.; Pessina, F.; Carullo, G.; Brizzi, A.; et al. Pinocembrin and its linolenoyl ester derivative induce wound healing activity in HaCaT cell line potentially involving a GPR120/FFA4 mediated pathway. Bioorg. Chem. 2021, 108, 104657. [CrossRef]

42. Farías, J.G.; Carrasco-Pozo, C.; Carrasco Loza, R.; Sepúlveda, N.; Álvarez, P.; Quezada, M.; Quiñones, J.; Molina, V.; Castillo, R.L. Polyunsaturated fatty acid induces cardioprotection against ischemia-reperfusion through the inhibition of NF-kappaB and induction of Nrf2. Exp. Biol. Med. 2017, 242, 1104-1114. [CrossRef]

43. Pérez, A.G.; León, L.; Pascual, M.; de la Rosa, R.; Belaj, A.; Sanz, C. Analysis of Olive (Olea Europaea L.) Genetic Resources in Relation to the Content of Vitamin E in Virgin Olive Oil. Antioxidants 2019, 8, 242. [CrossRef]

44. Bontempo, L.; Paolini, M.; Franceschi, P.; Ziller, L.; García-González, D.L.; Camin, F. Characterisation and attempted differentiation of European and extra-European olive oils using stable isotope ratio analysis. Food Chem. 2019, 276, 782-789. [CrossRef]

45. Bocci, V.; Valacchi, G. Nrf2 activation as target to implement therapeutic treatments. Front. Chem. 2015, 3, 4. [CrossRef]

46. Valacchi, G.; Virgili, F.; Cervellati, C.; Pecorelli, A. OxInflammation: From subclinical condition to pathological biomarker. Front. Physiol. 2018, 9, 858. [CrossRef] [PubMed]

47. Ferrara, F.; Woodby, B.; Pecorelli, A.; Schiavone, M.L.; Pambianchi, E.; Messano, N.; Therrien, J.P.; Choudhary, H.; Valacchi, G. Additive effect of combined pollutants to UV induced skin OxInflammation damage. Evaluating the protective topical application of a cosmeceutical mixture formulation. Redox Biol. 2020, 34, 101481. [CrossRef] [PubMed]

48. Pecorelli, A.; Cervellati, C.; Hayek, J.; Valacchi, G. OxInflammation in Rett syndrome. Int. J. Biochem. Cell Biol. 2016, 81, $246-253$. [CrossRef]

49. Pecorelli, A.; Cordone, V.; Messano, N.; Zhang, C.; Falone, S.; Amicarelli, F.; Hayek, J.; Valacchi, G. Altered inflammasome machinery as a key player in the perpetuation of Rett syndrome oxinflammation. Redox Biol. 2020, 28, 101334. [CrossRef]

50. Tian, C.; Liu, X.; Chang, Y.; Wang, R.; Lv, T.; Cui, C.; Liu, M. Investigation of the anti-inflammatory and antioxidant activities of luteolin, kaempferol, apigenin and quercetin. South Afr. J. Bot. 2021, 137, 257-264. [CrossRef]

51. Camargo, A.; Rangel-Zuñiga, O.A.; Haro, C.; Meza-Miranda, E.R.; Peña-Orihuela, P.; Meneses, M.E.; Marin, C.; Yubero-Serrano, E.M.; Perez-Martinez, P.; Delgado-Lista, J.; et al. Olive oil phenolic compounds decrease the postprandial inflammatory response by reducing postprandial plasma lipopolysaccharide levels. Food Chem. 2014, 162, 161-171. [CrossRef] 
52. Zhou, Z.; Zhang, L.; Liu, Y.; Huang, C.; Xia, W.; Zhou, H.; Zhou, Z.; Zhou, X. Luteolin Protects Chondrocytes from $\mathrm{H}_{2} \mathrm{O}_{2}$-Induced Oxidative Injury and Attenuates Osteoarthritis Progression by Activating AMPK-Nrf2 Signaling. Oxid. Med. Cell. Longev. 2022, 2022, 5635797. [CrossRef]

53. Cicek, M.; Unsal, V.; Doganer, A.; Demir, M. Investigation of oxidant/antioxidant and anti-inflammatory effects of apigenin on apoptosis in sepsis-induced rat lung. J. Biochem. Mol. Toxicol. 2021, 35, e22743. [CrossRef]

54. Vanhoutte, P.M.; Shimokawa, H.; Feletou, M.; Tang, E.H.C. Endothelial dysfunction and vascular disease-A 30th anniversary update. Acta Physiol. 2017, 219, 22-96. [CrossRef]

55. Carullo, G.; Ahmed, A.; Fusi, F.; Sciubba, F.; Di Cocco, M.E.; Restuccia, D.; Spizzirri, U.G.; Saponara, S.; Aiello, F. Vasorelaxant Effects Induced by Red Wine and Pomace Extracts of Magliocco Dolce cv. Pharmaceuticals 2020, 13, 87. [CrossRef] [PubMed]

56. Carullo, G.; Durante, M.; Sciubba, F.; Restuccia, D.; Spizzirri, U.G.; Ahmed, A.; Di Cocco, M.E.; Saponara, S.; Aiello, F.; Fusi, F. Vasoactivity of Mantonico and Pecorello grape pomaces on rat aorta rings: An insight into nutraceutical development. J. Funct. Foods 2019, 57, 328-334. [CrossRef]

57. Ditano-Vázquez, P.; Torres-Peña, J.D.; Galeano-Valle, F.; Pérez-Caballero, A.I.; Demelo-Rodríguez, P.; Lopez-Miranda, J.; Katsiki, N.; Delgado-Lista, J.; Alvarez-Sala-Walther, L.A. The Fluid Aspect of the Mediterranean Diet in the Prevention and Management of Cardiovascular Disease and Diabetes: The Role of Polyphenol Content in Moderate Consumption of Wine and Olive Oil. Nutrients 2019, 11, 2833. [CrossRef] [PubMed]

58. Saponara, S.; Carosati, E.; Mugnai, P.; Sgaragli, G.; Fusi, F. The flavonoid scaffold as a template for the design of modulators of the vascular Ca v1.2 channels. Br. J. Pharmacol. 2011, 164, 1684-1697. [CrossRef]

59. Fusi, F.; Spiga, O.; Trezza, A.; Sgaragli, G.; Saponara, S. The surge of flavonoids as novel, fine regulators of cardiovascular Cavchannels. Eur. J. Pharmacol. 2017, 796, 158-174. [CrossRef]

60. Ilic, S.; Stojiljkovic, N.; Stojanovic, N.; Stoiljkovic, M.; Mitic, K.; Salinger-Martinovic, S.; Randjelovic, P. Effects of oleuropein on rat's atria and thoracic aorta: A study of antihypertensive mechanisms. Can. J. Physiol. Pharmacol. 2021, 99, 110-114. [CrossRef] [PubMed]

61. Ali, S.F.; Woodman, O.L. Tocotrienol Rich Palm Oil Extract Is More Effective Than Pure Tocotrienols at Improving EndotheliumDependent Relaxation in the Presence of Oxidative Stress. Oxid. Med. Cell. Longev. 2015, 2015, 150829. [CrossRef] [PubMed]

62. Carullo, G.; Badolato, M.; Aiello, F. Chapter 26-Bioavailability and Biochemistry of Quercetin and Applications to Health and Diseases. In Polyphenols: Mechanisms of Action in Human Health and Disease, 2nd ed.; Watson, R.R., Preedy, V.R., Zibadi, S., Eds.; Academic Press: Cambridge, MA, USA, 2018; pp. 361-371, ISBN 978-0-12-813006-3.

63. Carullo, G.; Aiello, F. Quercetin-3-oleate. Molbank 2018, 2018, 7-10. [CrossRef]

64. Menendez, C.; Dueñas, M.; Galindo, P.; González-Manzano, S.; Jimenez, R.; Moreno, L.; Zarzuelo, M.J.; Rodríguez-Gómez, I.; Duarte, J.; Santos-Buelga, C.; et al. Vascular deconjugation of quercetin glucuronide: The flavonoid paradox revealed? Mol. Nutr. Food Res. 2011, 55, 1780-1790. [CrossRef] 